\title{
Risks, Returns and Relational Lending: \\ Personal Ties in Microfinance
}

\author{
Laura Doering \\ Rotman School of Management \\ University of Toronto
}

August 25, 2017

\begin{abstract}
Personal relationships are a common feature of financial intermediation. However, existing research offers different expectations about whether personal ties prove detrimental or beneficial for lenders. Research on embeddedness from economic sociology highlights the advantages lenders accrue when they develop personal ties with borrowers, including enhanced trust, information-sharing and greater social control. Yet research from social psychology offers reason to suspect that personal relationships can be costly because lenders who feel personally tied to borrowers run the risk of escalating commitment to poor performers. Drawing on these lines of research, this study uses data from a Latin American microfinance bank to ask: When are personal relationships detrimental or beneficial for financial intermediaries? It shows that, when lenders and borrowers have personal relationships, lenders are less likely to cut ties with poor performers and borrowers miss fewer payments, consistent with expectations from both literatures. However, these trends vary with frequency of contact. When lenders and borrowers interact less frequently, lenders continue to show heightened commitment, but borrowers become less compliant, creating potential problems for lenders. Overall, this study integrates theories from economic sociology and social psychology to offer a more balanced, temporally-informed understanding of personal ties in finance.
\end{abstract}

Forthcoming at American Journal of Sociology.

I am grateful to Mario Small, Elizabeth Pontikes, Rodrigo Canales, Richard Taub, and Ray Reagans for reading multiple drafts of this manuscript and providing continued support. I am also grateful for helpful comments from Anne Bowers, Jillian Chown, Jan Doering, Matissa Hollister, Sarah Kaplan, Chris Liu, Bill McEvily, Elena Obukhova, Jayanti Owens, Amanda Sharkey, András Tilcsik, Tiantian Yang, and Peter Younkin, as well as from seminar audiences at Brown, Chicago, Columbia, London Business School, Lugano, New York University, Princeton, and the University of Toronto. Finally, my deepest thanks to MicroBank administrators, loan officers, and clients for making this study possible. 
Scholars across a range of disciplines recognize the importance and pervasiveness of personal relationships in the financial sector (Abolafia 1996; Berger and Udell 1995; Mizruchi and Stearns 2001; Petersen and Rajan 1994). In lending institutions, personal ties between financial intermediaries (lenders) and clients (borrowers) influence how banks distribute capital and overcome information asymmetries (Berger, Klapper, and Udell 2001; Uzzi 1999). From initial capital allocation to loan repayment, personal relationships play an essential role in shaping financial transactions between intermediaries and clients (Canales and Greenberg 2015; Karlan, Morten, and Zinman 2015).

Although scholars across disciplines acknowledge that personal relationships influence financial intermediation, existing research offers seemingly divergent expectations about whether such relationships are detrimental or beneficial for lenders. For instance, research on embeddedness from economic sociology has documented numerous advantages associated with personal relationships in economic transactions. This research shows various ways in which embedded relationships — ties marked by personal familiarity and attachment (Uzzi 1997)—help actors avoid or overcome problems with economic alters. Researchers have demonstrated that intermediaries and clients who have embedded rather than arm's-length relationships share more fine-grained information about problems (Uzzi and Lancaster 2003), trust one another in times of uncertainty (Mizruchi and Stearns 2001), and can influence one another's behavior through social control mechanisms (Portes and Sensenbrenner 1993). From the intermediary's perspective, these features of embedded relationships should facilitate successful lending outcomes. Although scholars also note the potential pitfalls of personal ties (Mizruchi and Stearns 2001; Uzzi 1997), "the thrust of the literature has overwhelmingly dealt with positive aspects of embeddedness" (Krippner and Alvarez 2007, 226), suggesting that intermediaries 
should be well-positioned to avoid or resolve problems with clients when they have personal relationships.

Yet research on "escalation of commitment" from social psychology offers reason to expect that personal ties can prove problematic for intermediaries. Escalation of commitment refers to the tendency to remain committed to a struggling investment even after receiving objectively negative feedback about its performance (Staw 1976). Scholars have shown that actors escalate by making additional financial commitments (Staw 1976) or by investing continued time and effort in poor performers (Staw, Barsade, and Koput 1997; Guler 2007; Staw and Hoang 1995). Researchers view escalation as an erroneous choice because actors' decisions appear to be motivated by their sense of personal responsibility for the investment, when instead they should heed objective warning signs about performance. Researchers demonstrate that actors who feel personally responsible for investments are more likely to escalate commitment (Brockner 1992; Kelly and Milkman 2013). Financial intermediaries who engage in "relational lending" should be particularly prone to escalation because they develop personal ties with clients as a means of evaluating creditworthiness. Since personal relationships heighten feelings of responsibility and commitment to economic alters (Seabright, Levinthal, and Fichman 1992), lenders who have personal ties with clients may remain committed even when those clients underperform.

Existing research on embeddedness and escalation suggests that personal ties between intermediaries and clients can be both beneficial and problematic for financial intermediaries. However, the specific conditions under which these relationships prove more helpful or harmful remain unclear. In this paper, I aim to clarify these conditions and, in so doing, integrate distinct theoretical perspectives from social psychology and economic sociology to offer a more 
comprehensive understanding of how personal ties shape financial intermediation. In particular, I focus on frequency of contact as a key factor moderating financial outcomes. Frequency of contact is an important component of tie strength (Granovetter 1973; Homans 1950), with relationships generally becoming stronger with more frequent interactions. For financial intermediaries, this means that the degree to which they enjoy benefits—or incur costs—-from personal ties may vary with the frequency at which they interact with clients.

To examine this possibility, I draw on qualitative and quantitative data from "MicroBank,"1 a commercial microfinance bank in Latin America that is well-suited to investigating personal ties in financial intermediation. As a result of MicroBank's organizational practices, loan officers have either personal or arm's-length client relationships. Although in most settings relationships are endogenous to partner characteristics, in this setting relationships result primarily from exogenous organizational practices. At MicroBank, branch managers quasirandomly assign officers to clients, helping to isolate the effect of personal relationships on lending outcomes and minimize the likelihood of alternative explanations. Additionally, the longitudinal loan repayment data reveals changes in officers' and clients' behavior over time. The microfinance context thus allows for an analysis of how lending outcomes vary when intermediaries and clients have personal or arm's-length relationships, as well as how those trends change with shifting interaction frequency.

The results reveal the contingencies of personal ties as relationships evolve. When officers and clients have personal relationships, officers are less likely to cut ties with struggling clients, as escalation research predicts. Also consistent with expectations from embeddedness research, clients are more compliant (miss fewer payments) when they have personal

\footnotetext{
${ }^{1}$ This name is a pseudonym. The confidentiality agreement with the organization prohibits disclosing its name or country location.
} 
relationships with officers. However, the effects of personal relationships shift with interaction frequency. In this context, officers and clients establish personal ties through an initial vetting process that requires intensive interactions. Yet once loans are approved, officers and clients rarely interact. As relationships fade over time, officers continue to demonstrate heightened commitment to clients, but clients become less compliant. Thus, high-contact personal relationships show a match between commitment and compliance, but low-contact relationships show less alignment, with heightened commitment from officers met by decreased compliance from clients. These findings reveal how, as relationships shift in strength, the value of personal ties can change from being mutually beneficial to proving costly for financial intermediaries.

This study integrates theories from economic sociology and social psychology to offer a more comprehensive understanding of how personal relationships affect lending outcomes. In doing so, it advances theory about the contingencies of embeddedness in economic life- $-\mathrm{a}$ project identified as crucial for economic sociology (Krippner and Alvarez 2007)—and reveals the relational conditions under which escalation of commitment may prove a rational, strategic choice. Additionally, it highlights the speed at which personal relationships lose their potency in shaping economic outcomes if they are not maintained. Across a variety of organizations, intermediary-client ties start out strong and predictably fade over time. This research clarifies how such "front-heavy" relationships can systematically influence outcomes in a variety of organizations. Overall, this paper provides new insights into the shifting costs and benefits associated with personal relationships when those ties are mediated by formal organizations. 


\section{COSTS AND BENEFITS OF PERSONAL TIES}

Before discussing the theoretical underpinnings of the study, it is important to briefly establish two key features of the research setting. First, at MicroBank, loan officers have personal relationships with clients they approve for loans and formal, arms'-length relationships with clients they inherit. Officers inherit clients through a quasi-random process of redistribution. When an officer exits the bank, branch managers reassign clients from the exiting officer's portfolio to officers working in neighboring areas. To ensure balanced portfolios, branch managers reshuffle clients among non-exiting officers. Pre-transfer inherited clients have similar repayment rates to non-transferred clients, suggesting that administrators do not selectively transfer problematic clients. ${ }^{2}$ Second, officers can opt to send poor-performing clients to the collections department, cutting off any further interaction with them. In this way, officers may choose to remain committed to clients or cut ties with them. I exploit this scenario to explore whether officers are more likely to remain committed to personally-tied clients. In the Data and Method section, I provide more detail about the processes of client reassignment and loan collections.

In what follows, I use existing literature to derive hypotheses about how relationships influence intermediaries' commitment and clients' compliance. Then, I use qualitative observations from MicroBank to contextualize the theorized processes in the research setting and tailor the hypotheses to the organizational context. (I include a description of the qualitative data collection in the Data Appendix.) Thus, I draw from existing theory to generate hypotheses and use qualitative observations to ground those expectations in the research setting.

\footnotetext{
${ }^{2}$ In the Robustness Checks section, I conduct further analyses to examine whether systematic differences in officer experiences, geographic location, network ties, and collateral affect lending outcomes.
} 
Escalation of Commitment: Personal Relationships as Potential Liabilities

Social psychological research on escalation of commitment offers reason to expect that personal relationships can facilitate sub-optimal decision-making. Escalation of commitment emerged as a central concept in decision theory when Staw (1976) demonstrated that individuals who felt personally responsible for failing investments subsequently contributed more funds to those investments. Staw identified escalation as a decision error because actors' decisions to support struggling investments seemed driven by their sense of personal responsibility, rather than objective performance indicators. Researchers have explored the psychological mechanisms that encourage escalation (Brockner 1992; Rubin and Brockner 1975; Caldwell and O'Reilly 1982; Conlon and McLean Parks 1987; Whyte 1986), demonstrating that individuals are more likely to escalate when they feel personally responsible for initial resource allocation.

Escalation is an act of persisting in one's commitment to a struggling investment, and such persistence can manifest in monetary and non-monetary forms. Although Staw (1976) first observed escalation in financial contributions to failing investments, scholars also examine escalation in situations where actors continue to invest time, social capital, and other nonmonetary resources in poor-performing investments. For example, authors have defined escalation as holding rather than writing off problematic loans (Staw, Barsade, and Koput 1997), maintaining ties with poor-performing financial investments (Guler 2007), and keeping rather than trading NBA players (Staw and Hoang 1995). In each of these examples, actors do not make additional financial commitments, but instead resist cutting ties with investments for which they feel responsible. In such cases, actors escalate by continuing to allocate time and effort to a person, product, or project that presents signs of poor-performance. 
Scholars demonstrate that escalation occurs across an array of investment activities. Escalation researchers view actors as making "investments" when they allocate resources in the uncertain hope that the marginal benefits will exceed the marginal costs (Rubin and Brockner 1975). Scholars treat a range of resource allocations as investments, including inventors' efforts to develop inventions (Astebro, Jeffrey, and Adomdza 2007), coaches' allocations of playing time (Staw and Hoang 1995), and bankers' dispersions of loan funds (Staw, Barsade, and Koput 1997). Whether investments occur in the stock market or on the basketball court, scholars view uncertain resource allocations as subject to escalation tendencies.

Personal relationships can encourage escalation by heightening actors' sense of responsibility. Scholars have shown that actors who have personal relationships with alters are less likely to cut ties, even when those relationships become problematic. For example, individuals are less likely to cut ties with exchange partners with whom they have personal ties, even when they no longer need their services (Seabright, Levinthal, and Fichman 1992). Additionally, actors resist walking away from problematic exchange relationships because they have difficulty justifying the sunk costs associated with developing those relationships, suggesting that relationships with time-intensive up-front investments encourage escalation (Delios, Inkpen, and Ross 2004). Such research suggests that intermediaries should be less likely to cut ties with clients with whom they have personal relationships and more likely to cut ties to clients with whom they have arm's-length relationships.

In the present study, I examine escalation among MicroBank loan officers. Specifically, I test officers' tendencies to cut ties or remain committed to clients, based on their personal or arm's-length relationships. MicroBank offers a particularly sharp setting for studying escalation because it mirrors the hallmark field study of escalation. In that study, researchers observed 
whether bank officials held or wrote off problem loans (Staw, Barsade, and Koput 1997) — an act that directly parallels officers' decisions to persist with struggling clients or send them to collections.

I now turn to interviews and field observations from MicroBank to contextualize the expectation that intermediaries will be less likely to cut ties with personally-embedded clients. I use qualitative observations to tailor the hypothesis — presented formally at the end of this section - to the specifics of the MicroBank setting. I repeat this use of qualitative material to contextualize the second and third hypotheses.

At MicroBank, loan officers develop personal relationships with clients when vetting them for loans. Officers employ "relational lending" evaluation strategies (Berger, Klapper, and Udell 2001; Berger and Udell 1995) because the majority of new clients do not have credit histories. Facing steep information asymmetries, officers spend time with clients to assess their creditworthiness. MicroBank policy dictates that officers visit applicants at their homes and businesses. In these intimate settings, officers talk with clients about their families, financial situations, and plans for the loan. If the applicant has a spouse, the officer meets with him or her as well. Officers also interview community members to solicit an impression of the applicant's local reputation. Given the extent of information officers collect, they must spend at least two hours in conversation with applicants and generally make multiple visits. If loans are approved, officers assume responsibility for monitoring loans, which have a median term of 18 months.

As officers and clients get to know one another, their newly-formed relationships contain the key features of embeddedness: familiarity, personal attachment, and fine-grained information sharing (Granovetter 1985; Uzzi 1999). For simplicity, I refer to officers and clients paired 
during the vetting process as "original officers" and "original clients." The field note below captures the personal nature of the vetting process.

[The potential client] and his wife greet us at the door and invite us to sit in their living room. Hernán ${ }^{3}$ [the loan officer] and Amaya [the trainee] chat with the man for about 20 minutes before asking any questions about his business. Hernán asks the man, who is from Colombia, about the cultural differences between [this country] and his home country. His wife brings each of us a small cup of Colombian coffee and chimes in about the difficulties of living far from family. As we chat, their four-year-old niece sits on the floor at the foot of couch watching television. It isn't until everyone has finished their coffee that Hernán begins asking about the man's business supplies, expenses, and monthly earnings. Even then, the conversation is naturally interspersed with discussions about cultural differences and the family's relatives in Colombia.

Although officers work primarily with original clients, they are also assigned to clients approved by other officers. I refer to officers and clients who are subsequently reassigned as "inherited." Inherited pairings constitute approximately one-fifth of officer-client relationships. Officers learn they have inherited clients when they receive updated client lists from administrators, generally within 1-2 days of reassignment. Because original officers do not record fine-grained details about clients in boilerplate applicant reports, inherited officers do not have ready access to this information. And because officers manage upwards of 100 clients on average, they rarely contact new clients upon inheriting them. Instead, officers generally communicate with inherited clients only when problems arise. Clients, for their part, learn they have new officers when they receive their monthly bill, which lists the name of the officer overseeing the loan. Such formal relationships exemplify the "lean and sporadic transactions" (Uzzi 1999, 483) characteristic of arm's-length ties.

Officers thus have two types of client relationships: 1) personal relationships with original clients characterized by intensive, familiar interactions during the vetting process and 2)

${ }^{3}$ All names are pseudonyms. 
arm's-length relationships with inherited clients, with whom officers communicate only when necessary. Officers actively differentiate between these two client types. For instance, officers often develop an affinity for original clients. Describing client interactions during the vetting process, one officer noted, "You learn a lot from them" (female, age 29) and another remarked, "Sometimes we become friends with the clients. Sometimes we learn a lot from [them], and they learn a lot from us too" (female, age 30).

Additionally, officers describe a greater sense of personal responsibility for original clients. Two officers shared these opinions:

You feel responsible. Since I gave out the loan, the client has to pay. It's a responsibility that falls on me. It's not the same when a client falls behind on his payments and I'm not the one who gave him the loan. It's my responsibility because I did the analysis. I made the visit. [I] sign the document saying everything is correct. (female, age 40)

Recently, two months ago, I spoke with a client. I visited her. She's not a really bad client, but I feel that it's my responsibility because I did [the evaluation]. I brought her to the bank. I want all the clients I bring to the bank to be good clients. (female, age 30)

As these quotations demonstrate, officers feel a heightened sense of responsibility for the original clients they vetted and approved. Nonetheless, they are quick to point out that they care about their inherited clients - just not with the same intensity:

Inherited loans are our responsibility, too [...]. But... you work a little harder when it's your client because it was your job. You gave [the loan] to them. You did the analysis (male, age 19).

Officers' sense of personal responsibility may affect how they respond when clients fail to abide by contractual terms. Officers attempt to work with clients when they miss payments, but if they believe loans are unrecoverable, they have the option of sending clients to the collections department. Once this happens, officers and clients have no further interaction and

\footnotetext{
${ }^{4}$ Interviews were conducted in Spanish and recorded. Quotations are translated by the author.
} 
collections officers assume responsibility for the loan. Officers, in consultation with branch managers, have discretion over sending clients to collections.

The literature on escalation suggests that, because officers feel greater responsibility for original clients, they will show heightened commitment to those clients even when they underperform. When original clients miss payments, officers face classic escalation triggers: they feel responsible for the initial allocation of resources; they have repeated opportunities to act on objectively negative feedback (missed payments); and the likelihood of goal attainment is uncertain (Brockner 1992). Moreover, officers' personal ties to original clients may heighten their sense of responsibility (Broschak 2004), making it more difficult to send them to collections despite evidence suggesting they were weak initial investments. By comparison, officers are not responsible for allocating capital to inherited clients and do not have personal ties with them. In accordance with literature on escalation, I anticipate:

Hypothesis 1: Officers will be less likely to send original clients to collections than inherited clients.

Personal Relationships as Assets

Although the literature discussed above suggests potential costs associated with personal ties, research on embeddedness — developed primarily in economic sociology—proposes boons associated with personal ties in the financial sector. ${ }^{5}$ Such work demonstrates that personal relationships can facilitate transactions through heightened trust, information sharing and social control. In the context of financial intermediation, this research suggests that clients should be more compliant when they have personal relationships with intermediaries. In relational lending,

\footnotetext{
${ }^{5}$ Research also suggests that network embeddedness can hinder financial transactions (e.g., Mizruchi and Stearns 2001). I focus on the positive returns to embeddedness because these outcomes have received the bulk of attention in the literature (Krippner and Alvarez 2007) and because they correspond most readily to the present research context.
} 
compliance involves both clients and lenders: clients comply by making payments on time and lenders encourage compliance by working with clients to facilitate repayment.

Personal ties may heighten compliance through increased social control. When actors conduct exchanges in the context of personal relationships, partners are more likely to abide by norms of reciprocity and fairness (Coleman 1990). For example, research on microfinance demonstrates that borrowers are more compliant when accountable to neighbors in lending groups (Armendariz de Aghion and Morduch 2005). Additionally, personal relationships allow actors to sanction one another more effectively for norm violation (Granovetter 1995; Geertz 1963). For instance, small business owners in tightly-knit communities are particularly susceptible to gift and loan requests, as community members can cite norms of generosity and reciprocity (Portes and Sensenbrenner 1993). These social control mechanisms should encourage compliance through increased possibilities for social sanctioning.

Another factor that may facilitate compliance is trust. In times of uncertainty, trust-a primary feature of embedded relationships (Chan 2009) — serves as an important lubricant for exchange. Trust allows exchange partners to "assume the best when interpreting another's motives and actions" (Uzzi 1997, 43). For instance, scholars show that bankers rely on those they trust when seeking information in precarious transactions (Mizruchi and Stearns 2001), and that, in the absence of formal institutions, agents extend credit only to those they trust (Guseva and Rona-Tas 2001). In lending contexts, trust may facilitate compliance by encouraging lenders to view clients as reliable and work with them productively should they miss payments.

Related to trust, information sharing can also facilitate compliance in personal relationships. Researchers have found that actors are more likely to share private information with embedded exchange partners (Uzzi and Lancaster 2003), that information travels more 
easily via dense relationships (Baker 1984), and that fine-grained information sharing among embedded exchange partners allows for effective coordination (Uzzi 1997). Information sharing may encourage compliance by providing lenders with the information they need to work effectively with clients to avoid problems or by helping them overcome problems should they occur.

The social mechanisms outlined above play out at MicroBank, where exchanges are governed not only by formal contracts, but also by norms of reciprocity. Original officers incur professional risks when lending to clients whose long-term creditworthiness is uncertain. Clients, in turn, often feel gratitude towards the original officers who approved their loans. As one officer described,

The client sees the loan officer as the one who gave him the loan. A lot of my clients will say to me, "Thanks so much for what you've done. Look at how the money that I asked for has helped my business. I've been able to grow [my business] thanks to the opportunity that you gave me." (male, age 31 )

Beyond expressing gratitude, clients can reciprocate by complying with the terms of their contracts. ${ }^{6}$ Clients who make timely payments demonstrate appreciation for the risks original officers incurred and prove that the risk was justified. However, if clients are transferred to inherited officers, the norms of reciprocity no longer apply. Clients feel personally indebted to specific original officers - who came to their home, met their family, and approved their loanrather than to MicroBank and its affiliates. As one officer explained, "Sometimes when I talk with [inherited] clients, they say, 'I didn't make this agreement with you. I made it with the other guy"' (male, age 42). When personal ties are broken, clients no longer feel as tightly bound to norms of reciprocity that encourage timely repayment.

\footnotetext{
${ }^{6}$ Clients are also motivated to repay loans because they want to develop healthy credit scores that facilitate future borrowing. This motivation should not differ between original and inherited clients.
} 
Personal officer-client relationships can also influence how effectively officers work with clients to get them back on track. For example, officers can activate clients' sense of personal indebtedness when they miss payments. Specifically, original officers can threaten to withdraw the trust they placed in clients when they approved the loan. Officers explain the tactic in this way:

The loan officer calls a client and says, "No, remember, I gave you that loan. I trusted you." And it's like the client has a responsibility not to the bank, but to us [the officers] because we're the ones who work with them. We're the ones who gave them the opportunity to grow their business. (male, age 19)

When they're your own clients [original clients], you tell them, "I explained this to you really well. You knew what this was like. I trust you. Don't make me lose that trust I have in you." (female, age 30)

Although original officers can activate clients' social obligations to encourage repayment, inherited officers cannot use this approach. Because inherited officers did not vet and approve clients, any threats to withdrawal trust would ring false.

Officers also enjoy higher levels of information sharing with original clients, which facilitates collaboration in difficult times. Officers talk with clients who miss payments to uncover the source of the problem and offer potential solutions. Because original officers established personal ties with clients during the vetting process, they have a foundation of previous interactions on which to gather information and offer suggestions. As one officer explained,

I've always believed we understand each other better when we communicate. So I try to understand what [the client's] problem is. [...] When it's a client who you know really well-you know the husband or wife and the children and you know where they live and you have other clients in the area where they live-you can figure out what's going on with that person. (male, age 42)

By comparison, inherited officers generally communicate with clients for the first time when they miss payments. Under these conditions, clients are unlikely to share details about personal 
problems, and officers - who know few details about clients - may struggle to elicit relevant information.

Additionally, officers may view inherited clients as simply irresponsible when they miss payments. That is, officers may assume the best when interpreting original clients' missed payments (temporary external setback), but assume the worst when interpreting inherited clients' missed payments (general irresponsibility). Officers use specific terminology to characterize clients they view as irresponsible, labeling them "fresh." One officer characterized "fresh" clients in this way:

We have clients who have had problems because of personal or family issues or because they lost their business or the business slowed down. But we also have clients who we call "fresh." For them it's just, "I don't want to" or "I can't." (male, age 42)

Another officer described fresh clients as individuals "who aren't in the habit of being responsible" (female, age 30). Unlike its English usage, "fresh" in the local Spanish vernacular denotes a durable personal characteristic. ${ }^{7}$ A fresh individual is irresponsible, disrespectful, and takes advantage of others. Officers' tendency to categorize problematic clients as either "fresh" or victims of circumstance parallels the tendency in American politics to distinguish between the “deserving” and "undeserving” poor (Gans 1995; Katz 1989). Inherited officers are more likely to view clients as "fresh" because they cannot elicit the same level of detailed information and do not trust them to behave responsibly. As a result, they may work with inherited clients less effectively when they miss payments, leading to greater overall missed payments.

Overall, the literature on embeddedness — brought to life by qualitative observations from MicroBank—suggests that clients should be more compliant when they have personal

\footnotetext{
${ }^{7}$ Loan officers identified "fresh" behavior as embedded within the broader cultural concept of juega vivo. Juega vivo is loosely defined as a self-serving mentality that manifests in rude, aggressive, or arrogant behaviors. Individuals can attribute nearly any perceived act of chicanery-from cutting in line to government embezzlement - as rooted in juega vivo culture.
} 
relationships with officers. Original clients are more likely to adhere to norms of reciprocity, which demand timely repayment on loans approved by original officers. If clients fail to abide by these norms, original officers can leverage clients' sense of social indebtedness, pressuring them to repay. Original officers also have heightened trust and more information, tools that make them more effective collaborators with problematic clients. Given these factors, I anticipate that clients with personal intermediary ties will show greater compliance.

Hypothesis 2: Clients paired with original officers will miss fewer payments than clients paired with inherited officers.

\section{Enduring Relational Effects?}

Thus far, I have focused on how different types of relationships (original or inherited) established via vetting or reassignment affect intermediaries' commitment and clients' compliance. However, these outcomes may also be shaped by the strength of the relationship, which can change over time. I follow Simmel (1971) in conceptualizing relationships as possessing a "basic duality" consisting of 1) a constant form or type and 2) a varying level of strength. Relational forms — such as "spouse" or "business partner" - carry a socially recognized set of features and responsibilities that remains relatively constant.

Yet within this constancy, the strength of the bond may fluctuate. Although relationship strength varies for many reasons, frequency of contact is a key source of tie strength (Granovetter 1973). Regular interpersonal contact allows actors to share information, build trust, and renew bonds (Rivera, Soderstrom, and Uzzi 2010). As Homans (1950, 7) succinctly summarized: "If [friends] do not meet, their friendship is apt to ebb away. Absence makes the heart grow fonder only for a short time." 
As exchange partners interact less frequently, they are less likely to enjoy the benefits of embeddedness. ${ }^{8}$ Partners who interact less frequently share less information, collaborate less effectively, and have a decreased capacity to influence alters' behavior (Gulati and Gargiulo 1999; Uzzi and Lancaster 2003). Thus, when exchange partners meet less frequently, they may struggle to avoid or overcome difficulties. More specifically, this literature would anticipate that actors are more compliant with the terms of exchange when their relational ties are strong and become less compliant when those ties weaken.

At MicroBank, changes in interaction frequency are a standard feature of original officerclient ties. Original pairs have relationships characterized by intense, high frequency interactions at the outset. However, once loans are approved, officers and clients rarely interact unless problems arise. Officers and administrators note that, ideally, officers would interact with clients on a regular basis. However, because officers manage large portfolios and must meet aggressive sales targets, frequent interactions with existing clients rarely occur. Thus, unlike contexts in which longer relationships equal stronger relationships (e.g., Karolyi 2013; Uzzi 1999), increased relationship duration in this context means weaker relationships. Following the initial, high-intensity vetting interactions, original relationships decline in strength as officers and clients rarely, if ever, come into contact.

Clients' sense of obligation to original officers is likely to be strongest immediately following the initial vetting process. Without regular interactions, clients' sense of indebtedness to the officers who approved them for loans may fade. As the field note below suggests, clients' behavior towards original officers can change drastically over time.

\footnotetext{
${ }^{8}$ In addition to positive outcomes, frequency of contact is also associated with negative outcomes, such as mitigated competition (Ingram and Roberts 2000). For the purposes of this study, I focus on the ways that frequency of contact facilitates exchange.
} 
As we are walking to the bus, Anita asks me what I thought about [the client she just evaluated]. I say that she seemed like a nice person, but might not have enough goods to cover the collateral. Anita laughs. "Everyone is a nice person when they're asking for a loan," she says. "Do people change a lot later on?" I ask. She rolls her eyes. "Of course!"

This officer's comment points to the shift that can occur in clients' behavior once the positive, productive ties established during the vetting process become a distant memory. Over time, clients may feel less indebted to the officers who originally approved their loans, and as a result, may become less compliant.

Additionally, original officers may become less effective in encouraging compliance as relationships weaken. Officers may find that their relational tactics with original clients are not as convincing when they have not interacted with them recently. For example, in an officertraining workshop, an administrator suggested that officers encourage original clients to resume payments by emphasizing collaboration and clients' obligations to officers.

[The administrator] suggested that, at first, when dealing with late payers, officers should approach clients in a friendly and supportive way by using lines like, "You made an agreement with me," "I'm on your side," and "Let's work together to figure this out." (field notes, March 2011)

Clients might be receptive to officers' relational claims immediately following the initial vetting; however, they may become less responsive to such efforts after months have elapsed since their last interaction.

Although the strong, positive ties between original officers and clients can shift over time, inherited officer-client relationships experience relatively little variation in strength. Inherited officers generally make contact with clients only when they miss payments. Upon making contact, the interaction is organized around resolving a problem. Although inherited officers may feel empathy towards new clients and genuinely wish to support them, they cannot establish the relational foundation constructed during the initial evaluation. Officers' heavy 
caseloads simply do not permit them to spend hours — much less days — with inherited clients, as they did with original clients during the vetting process. Moreover, inherited officer-client interactions lack the positive emotional valence associated with loan approval that colors original relationships. Whereas original relationships start out on an intense, positive note and decline in strength over time, inherited relationships maintain a relatively low, constant level of relational strength.

The weakening relationship between original officers and clients is likely to influence compliance. As time passes, original clients may feel a decreased need to reciprocate the trust that officers placed in them when approving the loan, and officers' ability to encourage repayment should decline. As a result, I expect that original clients will miss fewer payments in the months following the initial vetting and more payments as they become temporally distant from the initial vetting.

Hypothesis 3: Relationship duration will moderate repayment, such that original clients' tendency to miss fewer payments than inherited clients will diminish over time.

Although I expect relationship duration to moderate repayment, I do not expect it to affect officers' collections decisions (Hypothesis 1). Officers' sense of responsibility for allocating resources to original clients should not fade with time. Indeed, the general sentiment shared by officers - "I want all the clients I bring to the bank to be good clients" (female, age 30) - is unlikely to diminish through decreased client interactions. When presenting the results of Hypothesis 1, I include an additional analysis testing whether relationship duration moderates officers' tendency to send clients to collections. I find that officers' heightened commitment to original clients does not wane over time. 
Alternative Theories

I hypothesize that personal relationships will influence officers' commitment and clients' compliance. Yet a number of additional forces may affect these outcomes, as well. Researchers show that the degree of leniency intermediaries show borrowers may be influenced by intermediaries' experience or seniority (Thompson 1967), the level of leniency common in the local environment (Canales 2014), and clients' personal and financial characteristics — which intermediaries may use to anticipate future performance (Baklouti 2013; Haile 2015). To account for these factors at MicroBank, I control for officers' experience and personal characteristics, and I include branch fixed effects, as officers may be influenced by the leniency cultures in their branch offices. Additionally, I account for clients' social and financial characteristics—such as marital status, household income, and repayment history — since these factors may signal financial stability and sway officers' collections decisions.

Research on microfinance demonstrates that loan repayment is a function of officer and client characteristics, as well as loan structure. Clients are more likely to make timely payments to officers whose authority they view as legitimate (Doering and Thébaud 2017). To that end, I account for officer characteristics, such as gender and tenure, when predicting repayment. Loan repayment is also associated with clients' financial security and ability to recover from economic shocks (Sadoulet 2005), and has been linked to demographic characteristics like client gender and marital status (D'Espallier, Guerin, and Mersland 2013) — factors which I account for in the analyses. Additionally, loan repayment is a function of loan size, length, and type (Ang, Chua, and Bowing 1979; Bragg 2005), with microfinance clients often struggling to repay larger loans. I also control for these factors when predicting repayment. 
When measuring the effects of officer-client relationships on collections and loan repayment, I account for factors that previous researchers have linked to officer leniency and client compliance. In the Robustness Checks section, I also explore four alternative explanations related to officer quality, client communication patterns, social network effects, and financial uncertainty. I find the results robust to the inclusion of control variables, as well as to tests of alternative theoretical mechanisms.

\section{DATA AND METHOD}

MicroBank offers an excellent context to explore the effects of personal ties in financial intermediation. In the following analyses, I examine the month-by-month behaviors of officers and clients in order to estimate the relational conditions under which officers resist sending clients to collections, as well as the relational and temporal conditions under which clients repay loans on time. I use MicroBank's proprietary database of lending history, which contains monthly observations for each loan, demographic client information, and a code identifying which officer managed the loan each month from April 2009 to August 2012. Table 1 reports summary statistics for the 255,474 monthly observations corresponding to 19,721 loans. ${ }^{9}$

[Insert Table 1 about here.]

Modeling Collections.-Hypothesis 1 anticipates that officers will be less likely to send original than inherited clients to collections. To test this hypothesis, I employ a discrete-time event history model on the panel loan-month observations, with standard errors clustered by loans. I use a discrete rather than a continuous approach because collections events are recorded in discrete, monthly intervals (Allison 1982). I employ logistic regression, as this approach is

\footnotetext{
${ }^{9}$ Table 1 shows high correlations among a few variables. I ran a test of the variance inflation factor (VIF) to ensure multicollinearity did not bias the results. All VIF values fall at or under 5.03. This value is well below 10, the point after which results may be affected by multicollinearity (Neter, Wasserman, and Kutner 1989).
} 
well-suited to modeling discrete-time data (Allison 1982, 2014) and accommodates rightcensored observations from clients who had not yet finished repaying the loans at the end of the observation window (Allison 1984; Blossfeld, Golsch, and Rohwer 2007). For each nested model, I include chi-squared values generated from Wald tests that reflect whether each new variable significantly improves model fit. Since these fit statistics evaluate the predictive value of the individual variables introduced, I do not include chi-squared values for the initial, baseline models.

Because only 321 clients are sent to collections, I also estimate the collections outcome using a rare-event logistic regression. Logit estimates become biased when the unconditional probability of a binary event is low, even when the overall observation count is high (King and Zeng 2001). Rare event logistic regression corrects coefficient estimates and standard errors to account for the systematic bias attributable to the low unconditional mean of the dependent variable (King and Zeng 2001). I present both the discrete-time logistic regression and the rare event logistic regression models as complementary estimates of officers' commitment tendencies.

Modeling Missed Payments.-Hypothesis 2 anticipates that clients will miss fewer payments when paired with original officers. Because missed payments are discrete, repeatable events, I use a repeated-event estimation strategy (Allison 1982). Clients are "at risk" of missing payments each month, beginning with the first monthly payment. Repeated-event models require specification of the risk interval relative to a particular starting point (Box-Steffensmeier and Zorn 2002). In this case, clients' propensities to miss payments are likely to be affected by the duration of the loan. I include a loan month covariate to account for loan duration, which 
measures elapsed months since the start date (Allison 2014). ${ }^{10}$ I use logistic regression to model the likelihood of missed payments as it accommodates repeated events, time-varying covariates, as well as data censoring associated with observations from clients who have not yet finished repaying their loans (Allison 1982, 2014).

Modeling Interactions.-Hypothesis 3 proposes that original clients' superior repayment tendencies will diminish over time as the frequency of original officer-client interaction declines. To evaluate this possibility, I interact officer-client relationship type (original or inherited) with relationship duration. In this setting, original officer-client relationships start off strong as a result of the personalized vetting process and predictably weaken over time as the frequency of contact drops off.

When interpreting interaction effects, I rely on predicted probabilities because the magnitude and significance of interaction coefficients can be misleading in non-linear models like logistic regression (Ai and Norton 2003; for applied examples see Kwon, Heflin, and Ruef 2013; Doering and Thébaud 2017). I present these results graphically to aid interpretation, charting predicted outcomes for 1 to 18 months of relationship duration. Loans are repaid within 14.06 months on average, and $92 \%$ of all monthly observations occur within 18 months of relationship duration.

One concern associated with testing interactions is that inherited clients have experienced more months of repayment than original clients at the same level of officer-relationship duration. For example, imagine that an inherited and original client have been paired with their officers for two months. If the inherited client experienced a transfer after five months with an original officer, then the inherited client would be on the seventh month of repayment ( 5 months with

\footnotetext{
${ }^{10}$ Another way of establishing the risk interval is accounting for "gap time," or, in this case, the time between missed payments (Ezell, Land, and Cohen 2003). I did not chose this approach because I am less interested in the passage of time between events and more interested in the overall level of missed payments.
} 
original officer +2 months with inherited officer $=7$ months total). By comparison, the original client would be on the second month of repayment ( 2 months with original $=2$ months total). Thus, differences in lending outcomes may reflect inherited clients' longer repayment durations at the same levels of relationship duration.

I take two steps to account for this possibility. First, in the main models, I control for loan month, which accounts for systematic differences in original and inherited clients' total repayment time. Then, as an additional check (available upon request), I reran the models excluding inherited clients transferred after more than three months with original officers. The remaining inherited clients have officer-relationship durations similar to those of original clients. The results are robust to this specification.

Key Features of the Research Setting

Two features of the setting warrant special attention: inherited client redistribution and the collections process. I provide detail about these processes to highlight how my analytic strategy aligns with MicroBank's organizational practices.

Inherited Client Redistribution.-Officers inherit clients through a quasi-random redistribution process overseen by branch managers. The quasi-random nature of this process is important because it minimizes the possibility that factors other than relationships drive differences in lending outcomes. When an officer exits the bank, the branch manager reassigns the exiting officer's clients to one or more remaining officers. To achieve caseload balance and closer proximity to clients, managers transfer clients from a receiving officer's portfolio to remaining officers whose geographic zones border that of the exiting officer. Furthermore, 
managers work to ensure that officers are not burdened with unduly large caseloads. In this way, the exit of one officer triggers a domino effect of client redistribution across the branch.

Descriptive analyses of client characteristics suggest that branch managers do not selectively transfer problematic clients. Before being transferred, inherited clients have similar missed payment rates to clients who are never transferred. Pre-transfer inherited clients miss on average $12.2 \%$ of payments, whereas clients who are never transferred miss $13.1 \%$ of payments. Qualitative observations also support the notion that client redistribution is driven primarily by the need to equilibrate portfolios. In the words of one senior loan officer,

[When the manager] divides up the old portfolio, [he or she] doesn't say, "Oh, these are good borrowers so I'm going give them to this loan officer." No. It's divided equally. They try to ensure that the portfolios are balanced. (male, age 31)

Additionally, officers' payment structure does not encourage them to distinguish between original and inherited clients, nor does it prompt them to favor clients they approved for loans. Officers receive a base salary as well as a monthly commission driven by the number of new clients they recruit and the percentage of on-time payments in their portfolio. Officers do not receive special financial incentives for securing repayment among original clients. Additionally, MicroBank does not increase interest rates when clients miss payments; it is financially advantageous for officers and the bank to have clients who make payments on time.

Collections. - When testing Hypothesis 1, I examine officers' tendency to remain committed to original clients by observing the likelihood of sending them to collections. Importantly, officers have discretion over this outcome. MicroBank has no official policy on when clients must be sent to collections, but instead relies on officers—in collaboration with branch managers - to make this decision, with most officers opting to persist with problematic clients. 
Officers and administrators emphasize that sending clients to collections can negatively impact the bank and should not be taken lightly. As other scholars have noted, the act of removing collateralized goods from clients' homes is often an emotional and public event (Hochschild 1983; Battilana and Dorado 2010). One officer emphasized that collecting collateral is never the bank's goal: "[MicroBank] is not in the business of selling people's used refrigerators" (field notes, December 2009). Clients who are transferred to collections have no further interaction with their loan officers and instead work exclusively with collections officers.

Nevertheless, if an officer feels certain that a client will not resume payment, sending that client to collections is a reasonable course of action. MicroBank incurs financial and opportunity costs when officers continue to work with clients who repeatedly miss payments. Moreover, the credible threat of collections can deter clients who might prefer to miss payments.

\section{Dependent and Independent Variables}

Dependent Variables.-H1 anticipates that officers will be less likely to send original than inherited clients to collections. $\mathrm{H} 2$ anticipates that clients will miss fewer payments with original than inherited officers, and $\mathrm{H} 3$ anticipates that these effects will attenuate over time. The dependent variable used to test $\mathrm{H} 1$ captures whether a client is sent to the collections department by his or her loan officer. This variable takes a value of 0 every month the client is not sent to collections and 1 in the month that a client is sent to collections. The collections outcome constitutes the end of the officer-client relationship. The dependent variable associated with $\mathrm{H} 2$ and $\mathrm{H} 3$ measures whether a client made or missed a payment in each monthly observation $(1=$ missed payment). 
Independent Variables.-The primary independent variable of interest, original officer, captures whether the officer in charge of an account was the original vetting officer or an inherited officer (original officer $=1$ ). Each officer has a unique identifying code. The officer in charge of a loan in the first month is the original officer. If a loan is transferred to another officer, that loan is coded as "inherited." I lag inherited status by one month to ensure officers and clients have time to recognize the new pairing. To examine moderating effects, I interact original officer with relationship duration, a variable that captures the number of months officers and clients were paired at the focal observation.

Control Variables.-Following the literatures on credit, decision-making, and compliance, I anticipate that officer and client characteristics will affect lending outcomes. The first set of variables accounts for the fact that officers' experiences and status characteristics may affect collections decisions and loan repayment. Because experienced professionals tend to be more confident taking action under uncertainty (Thompson 1967), experienced officers may be more likely to walk away from struggling clients. Additionally, experienced officers may have subtler and more effective strategies for working with clients. To account for these factors, I control for officers' tenure with MicroBank. Similarly, I control for officers' monthly commission because officers' success in meeting organizational expectations may influence their engagement with problematic clients, as well as their willingness to cut ties. Additionally, gender has been shown to influence how managers enact authority and the compliance afforded to them by subordinates (Ridgeway 2009; Doering and Thébaud 2017). To account for these factors, I control for officer gender, as clients may be less compliant with female officers. Finally, officers may be influenced by the overall level of leniency in their work environments (Canales 2014). In 
testing H1, I include branch fixed effects because administrators at each branch may encourage different levels of leniency in collections.

Research also suggests that borrowers' characteristics may affect commitment and compliance. Clients' repayment tendencies should be influenced by the size and length of their loans, as well as their repayment histories (Ang, Chua, and Bowing 1979; Bragg 2005). To that end, I control for loan month, or the number of months elapsed since origination, loan amount including interest, whether the loan was an automobile or working capital loan, and whether the client has a previous MicroBank loan. Additionally, when testing H1, I control for the proportion of balance remaining on the loan and the cumulative missed payments, because officers may be swayed by clients' remaining balances and overall payment history when making collections decisions. When making such complex decisions, officers may rely on simplified heuristics about clients (Espeland and Stevens 1998), attending to signals of financial stability that affect repayment (Baklouti 2013; Haile 2015). Thus, I control for household income, household debt, family size, and marital status. I code common-law partners as married. ${ }^{11} \mathrm{I}$ also control for client gender, as some research has found that women repay microfinance loans more reliably than men (D’Espallier, Guerin, and Mersland 2013).

Two final details are worth noting. First, some covariates have the potential to change at each monthly observation, including original officer, relationship duration, officer tenure, commission, loan month, remaining balance, and cumulative missed payments. All other covariates are constant within loans. Second, to improve model fit, I include the natural log of relationship duration, commission, loan amount, household income, and household debt. Including the logged value of relationship duration reduces collinearity with loan month.

\footnotetext{
${ }^{11}$ I ran additional models that also controlled for officer caseload, officer age, client age, interest rate, and number of children. These measures do not affect the significance or directionality of the key independent variables, so I exclude them in the interest of parsimony.
} 


\section{RESULTS}

\section{Commitment to Original Clients}

Drawing on social psychological theories of escalation, $\mathrm{H} 1$ predicts that officers will be less likely to send original than inherited clients to collections, given the personal relationship and heightened sense of responsibility officers feel towards original clients. Because the models control for missed payments, they evaluate officers' commitment to original and inherited clients with similar missed payment histories. Table 2 displays the results, with exponentiated coefficients reflecting the odds that a client will be sent to collections. Model 1 includes only the control variables and Model 2 introduces the key independent variable, original officer. Model 2 shows that, net a variety of controls, officers are $60.5 \%(1-.395=.605)$ less likely to send original clients to collections. The rare-event logistic regression in Model 3 offers similar results. These findings confirm H1: officers are less likely to send original clients to collections, instead opting to remain committed to problematic clients. The results also parallel officers' assertions that they feel a heightened sense of responsibility for original clients. As one officer summarized, "The difference between inherited clients and my clients [original clients] would be the responsibility I have because I gave the loan" (female, age 40).

\section{[Insert Table 2 about here.]}

I also examined whether relationship duration significantly moderates the effect of having an original officer in Models 4 and 5. I anticipated this effect to be non-significant because officers' greater sense of professional responsibility to original clients should not fade over time. Given that interaction coefficients in nonlinear models can be misleading (Ai and Norton 2003), I use the results of Model 4 to generate the predicted repayment probabilities at 
varying levels of relationship duration, holding all controls constant at their means. Figure 1 shows that, as expected, original officers are less likely to send original clients to collections, suggesting that their tendency to remain committed does not significantly diminish as the relationship weakens.

[Insert Figure 1 about here.]

The control variables are also informative about collections outcomes. Models 2 and 3 show that officers have greater odds of sending clients to collections when more time has elapsed since loan origination (loan month), implying that both original and inherited officers tend to walk away later rather than earlier in the loan. The models also show that officers have greater odds of sending clients to collections when they have higher remaining balances, more cumulative missed payments, more debt and larger families. Officers have lower odds of sending clients to collections as loan size increases.

Additionally, officers have greater odds of sending clients to collections when they have automobile loans rather than working capital loans. Because cars are valuable and easily moved, collections officers can repossess these items relatively easily. By comparison, collections officers may need to repossess a variety of smaller items from working capital clients. I explore the effects of collateral in greater detail in the Robustness Checks.

The main findings from Table 2 parallel escalation research, demonstrating that individuals who feel greater personal responsibility for resource allocation (Brockner 1992; Staw, Barsade, and Koput 1997) and have personal ties to investees (Delios, Inkpen, and Ross 2004; Seabright, Levinthal, and Fichman 1992) are less likely to walk away from struggling investments. Although escalation research traditionally views such commitment as erroneous, it is possible that officers persist with original clients because they view them as more reliable. 
Indeed, the qualitative data suggest that, as a result of their personal relationships, officers may communicate with and pressure original clients more effectively, and clients may be more inclined to uphold their obligations to the bank when paired with officers who approved their loans. Thus, original officers' heightened commitment may be matched by heightened compliance from original clients. The next set of analyses tests whether original clients miss fewer payments than inherited clients and examines how these trends change across officer-client relationship duration.

\section{Missed Payments}

In Hypothesis 2, I anticipate that original clients will be less likely to miss payments than inherited clients. In Hypothesis 3, I propose that the main effect of having an original officer will be temporary, with original clients missing more payments over time as the relationship weakens. The results are presented in Table 3, with exponentiated coefficients reflecting clients' odds of missed payments. Model 1 includes only the control variables and Model 2 introduces original officer. The results support Hypothesis 2: original clients have significantly lower odds of missed payments. The odds ratio from Model 2 is easiest understood as an inversion: inherited clients have $2.53(1.0 / 0.395)$ times greater odds of missed payments than their original counterparts. Holding all controls constant at their means, original clients have a 9.9\% predicted probability of missed payments, while inherited clients have a $21.7 \%$ probability of the same. These findings show that clients are more compliant with their contractual terms when paired with original officers.

[Insert Table 3 and Figure 2 about here.] 
In Model 3, I introduce an interaction between original officer and relationship duration. As above, I use predicted probabilities to evaluate effect significance at varying levels of relationship duration. Figure 2 shows that inherited clients' repayment tendencies remain relatively unchanged over time. By comparison, original clients' predicted probabilities of missed payments shift over the duration of their officer relationships. As anticipated, original clients miss significantly fewer payments in the early months of their officer pairings when the relationships are strongest. As the relationship weakens through infrequent interaction, original clients become increasingly likely to miss payments. The findings suggest that original clients' heightened compliance can be temporary, fading as the relationship weakens.

These results lend support to the notion that clients' repayment tendencies are significantly shaped by their officer relationships. Indeed, they parallel one administrator's observation about repayment:

We always say that [officers] have to develop almost an intimate relationship with [clients], because when you establish that person-to-person relationship, it makes them more resistant to missing payments. If I have a loan with so-andso, I'm going to pay her well. How am I going to miss a payment to her? Clients pay the bank because of the relationships that officers develop with them.

Yet the data also show that clients' tendency to comply in the context of personal relationships can fade over time. Original clients miss significantly fewer payments in the months immediately after the initial vetting, as compared to later in the loan.

These findings are particularly striking given MicroBank's competitive landscape.

MicroBank competes against a handful of other microfinance institutions that clients can approach for future loans. The presence of such institutions should encourage clients to repay loans diligently. Once clients begin repayment, they develop formal credit scores which other financial institutions use to assess their creditworthiness. As such, clients should be concerned 
about developing healthy credit scores independent of their officer relationships, as these scores are the key to future loans. Despite the strong incentives for timely repayment, the results show that clients' repayment nevertheless depends on the type and strength of their officer relationships.

Taken together, the results reveal the shifting costs and benefits of personal ties as relationships between clients and intermediaries evolve. When exchanges are embedded in personal relationships, intermediaries are more likely to remain committed and clients are more compliant. However, clients' compliance tendencies hinge on the strength of the relationship, which in this setting fades predictably over time. The results suggest shifting (dis)advantages associated with personal relationships, as intermediaries may continue to show heightened commitment even after they no longer enjoy compliance advantages.

\section{Robustness Checks}

I have argued that the type and strength of officer-client relationships drive the results above. However, it is important to consider alternative explanations. In what follows, I discuss and test four alternatives. First, because officer exits precipitate client transfers, it is possible that inherited clients are of lower quality than original clients. Second, original and inherited clients may live in different areas. If officers can communicate with original clients more easily, they may be more lenient with them (Uzzi 1997; Uzzi and Lancaster 2003). Third, original clients may be more socially connected to other MicroBank clients and this connectivity might influence officers' leniency and clients' compliance (Owens 2014; Portes and Sensenbrenner 1993). Fourth, officers' collections decisions could be shaped by the uncertainty associated with recouping their financial investment (Bragg 2005). I examine each of these alternatives below 
and find that the nature of officer-client relationships continues to drive the results even when accounting for these factors.

Non-Exiting Officers.-Officers inherit clients through a quasi-random redistribution process overseen by branch managers. Although MicroBank staff report that this process is impartial, it is nevertheless crucial to account for any potential biases. Officers leave the bank voluntarily (because they find better opportunities) or involuntarily (because they are fired). Officers who leave involuntarily may recruit weaker clients on average and their client interactions may encourage delinquency. Thus, the findings may be driven by lax vetting practices among some exiting officers. To test this possibility, I reran the models including only inherited clients who became inherited because they were "reshuffled" in an effort to balance officers' portfolios; I excluded clients who became inherited because their officers exited the bank. $^{12}$ The results (see Appendix A) are robust. Including only "reshuffled" inherited clients, I find that original officers are nevertheless more likely to remain committed and original clients miss fewer payments. These finding offer greater confidence that the results are not driven by a subset of inherited clients who had weak original officers.

Geographic Location.-Another alternative explanation relates to clients' geographic locations. Officers with clients in distant, rural areas incur greater transaction costs and may be more likely to exit the bank as a result. When these officers exit, their geographically-distant clients would become inherited clients in another officer's portfolio. In this scenario, inherited clients' location might underlie the findings, as officers might be less inclined to visit or communicate with distant clients. I examine this possibility by focusing on a sample of clients

\footnotetext{
${ }^{12}$ As an additional test, I considered whether non-exiting officers pass off weaker clients to other officers in the reshuffling process. I compared missed payment rates for reshuffled clients with those of clients who remain in their officers' portfolios and found no significant difference in average missed payments, suggesting that officers are not shedding weaker clients via the reshuffling process.
} 
who should be relatively easy for officers to access: urban dwellers. Analyzing this sample helps clarify whether outcomes differ for original and inherited clients even when they are located in similar geographic areas. The MicroBank database contains identifiable client locations at the town- or neighborhood-level for $87.5 \%$ of the full sample. I use census data to determine whether the client lives in an area classified as urban or rural and reran the models on urban clients only. Focusing on urban clients allows me to compare outcomes when both original and inherited clients live in relatively easy-to-access locations. ${ }^{13}$ The results (see Appendix B) demonstrate that, even when original and inherited clients are located in relatively easy-to-access areas, officers are less likely to send original clients to collections and original clients miss fewer payments. These results suggest that officer-client relationships drive the findings, rather than clients' geographic locations.

Network Ties.-Another alternative explanation relates to clients' social networks. Often, officers approve clients from interconnected social circles. When transfers occur, branch managers may redistribute socially connected clients across multiple officers. In this case, original officers would have more socially interconnected clients than inherited officers. As a result, original officers might resist sending clients to collections for fear of damaging relationships with other clients in their networks. Similarly, if original clients have more ties to other clients, they may miss fewer payments to avoid damaging the good standing of their network ties.

\footnotetext{
${ }^{13}$ I also ran the analyses controlling for urban/rural location and found the results robust. Additionally, I ran the models including community fixed effects. The advantage of this approach is that it facilitates within-community comparisons and allows for an analysis of clients who are similarly easy or difficult for officers to access. The disadvantage is that it requires variation on the dependent variable in each community; many communities lack variation and are automatically dropped. Nevertheless, the results of the community fixed effects models parallel the main models, providing greater confidence that personal relationships shape commitment and compliance.
} 
Ideally, one would use social network data to explore this possibility. Because MicroBank does not collect such information, I use clients' co-location in an urban neighborhood or rural town as a proxy for social ties. Clients who live in the same community and have the same officer are likely to have some kind of social tie, although this is not necessarily the case. I control for the number of local co-clients as a proxy for clients' network ties to other MicroBank borrowers, as well as community population to account for the fact that clients in larger communities may have more local co-clients. Because this analysis relies on identifying clients' communities, I analyze only those clients for which locational data is available. The results_-presented in Appendix C—are consistent with the main findings. In the absence of direct social network data, these analyses offer the closest feasible test of underlying network effects and offer greater confidence that personal relationships underlie lending outcomes.

Automobile Loans.-Officers' collections decisions may be driven by the value of clients' collateral. Results from Table 2 show that officers are more likely to send clients to collections when they have automobile loans as compared to working capital loans. Clients with auto loans have high value collateral (new cars), whereas clients with working capital loans pledge a variety of smaller, less valuable goods. I examine whether officers resist sending original clients to collections even when they have valuable collateral by re-testing $\mathrm{H} 1$ on only clients with auto loans. The results are attenuated but consistent: an original, auto loan client is less likely to be sent to collections than an inherited, auto loan client (see Appendix D). These findings suggest that personal relationships influence lending outcomes even among clients with high-value collateral. 


\section{CONCLUSION}

This paper draws on theories from social psychology and economic sociology to offer a more balanced, temporally-informed understanding of the value of personal relationships in financial intermediation. Social psychological research on escalation of commitment suggests that personal relationships can encourage intermediaries to remain committed to struggling clients, a potential decision error that overlooks objectively negative performance indicators. Yet theories of embeddedness from economic sociology show how personal relationships can facilitate greater compliance - a positive outcome for intermediaries - through heightened trust, information sharing, and social control. This study confirms the overall empirical validity of both perspectives, and also reveals how the anticipated outcomes shift with frequency of contact. Such trends come into sharp relief in this setting, where personal relationships between officers and clients begin on a strong note and fade predictably over time.

When personal relationships are strong, officers demonstrate heightened commitment to clients and clients demonstrate heightened compliance. This outcome is mutually beneficial: officers enjoy more reliable loan repayment and clients who fall behind enjoy greater leniency. However, as personal ties wane through decreased interaction, original clients become less compliant and more likely to miss payments, although original officers continue to show heighted commitment. Under these conditions, intermediaries with personal client relationships may remain committed even after those relationships cease to deliver performance advantages. In this way, the value of personal ties for financial intermediaries shifts as the relationship evolves. Personal relationships facilitate mutually beneficial outcomes when relationships are strong, but may become costly as relationships weaken and heightened commitment from intermediaries is no longer matched by heightened compliance from clients. 
Like any study, this one has important limitations. First, due to the nature of the data, it privileges officers' experiences and perspectives. Second, given that microfinance clients are credit-constrained, they may feel particularly indebted to original officers. Future research can fill these gaps by examining intermediary relationships from clients' perspectives and studying financial outcomes under varying degrees of resource dependency.

\section{Relational Escalation of Commitment}

The findings from this study provide a new lens for thinking about escalation of commitment. By incorporating insights from economic sociology, this study demonstrates that remaining committed to a struggling investment can be a rational choice, depending on the nature of the relationship between the investor and investee. Escalation of commitment is generally viewed as a decision error, since actors who escalate appear to overlook objectively negative feedback about struggling investments (Kelly and Milkman 2013; Schoorman 1988). "Investments" in this sense refer not only to traditional stock or equity investments, but to any act of resource allocation in which actors hope that marginal gains will exceed marginal costs (Rubin and Brockner 1975). Although some scholars have speculated that remaining committed to a struggling investment is not always problematic (Brockner 1992), this study is the first to my knowledge that systematically considers the conditions under which remaining committed to a problematic investment may constitute a strategic choice, rather than a decision error.

When viewing escalation as erroneous, scholars adopt the implicit assumption that all struggling investments are equally likely to continue on downward trajectories. Such an assumption is reasonable when investors and investments cannot influence each other, as when individuals invest in stocks. In most circumstances, individual investors cannot intervene to 
shape a stock's performance. If the stock plummets and has little likelihood of recovery, investors would be wise to walk away rather than persist. Escalation, in this case, would constitute a decision error because the investor's heightened commitment is unmatched by reasonable expectations of improved future performance.

Nevertheless, in many contexts, investors and investees $d o$ influence one another. When investors and investees are human and have personal ties, they can shape one other's behavior. For example, consider the case of venture capitalist (VC) investors and their investees. When vetting target firms, $\mathrm{VC}$ investors often spend time with leadership teams in informal settings (Bygrave and Timmons 1992; Campbell 2003), and in doing so, establish personal relationships. The personal ties between VC investors and firm leaders may influence firm performance. When relationships are new and strong, firm leaders might work harder to ensure excellent performance and justify the VC investment. And should the firm flounder, the investors are likely to show greater commitment than they would in the absence of personal ties. Although traditional escalation research would view continued commitment from investors as erroneous, findings from the present research suggest that such commitment may be justified — and even strategicif investees are more likely to demonstrate superior performance as a result of their personal ties to investors.

However, results from this study also show that investors' tendency to heighten commitment can outlast the point at which they enjoy improved relational returns. This finding, then, adds new reason to worry about escalation: when personal ties weaken, investors may overestimate investees' future performance as well as their ability to influence it. For instance, if VC investors rarely interact with members of the target firm after committing funding, team 
members in the target firm may exert less effort to prove the firm's worth and investors may have less capacity to influence performance.

Overall, this research highlights the importance of viewing escalation decisions in their relational context. Strong, personal relationships benefit intermediaries by facilitating heightened commitment matched by heightened performance. Yet in the absence of sustained contact, personal relationships can become problematic when investors continue to remain committed even when weakened ties no longer generate improved outcomes from investees.

\section{Front-Heavy Relationships}

Findings from this study also illuminate a particular form of organizational relationship that, although common, has received less attention in the literature. In many organizations, intermediaries and clients ${ }^{14}$ develop what might be termed "front-heavy" relationships. Here, I outline the features of front-heavy relationships, highlight potentially paradoxical aspects of such organizationally-mediated ties, and suggest promising avenues for future research.

In front-heavy relationships, intermediaries and clients have intensive, personal contact at the outset. Examples of front-heavy relationships include those established between parole officers and offenders at initial home visits, social workers and clients at the first intake meeting, as well as mortgage lenders and prospective home buyers during the loan application phase. By establishing personal relationships at an early stage, intermediaries solicit fine-grained, tacit information about clients, and clients gain a personal representative within an organization. Unlike friendships formed on the basis of affinity, intermediaries and clients have "complex relations" (Coleman 1990) in which personal ties serve to achieve utilitarian objectives. Once

\footnotetext{
${ }^{14}$ I use the term "client" to refer to fee-paying clients as well as beneficiaries of public services.
} 
they achieve those objectives, both parties have little reason to maintain the initial intensity of contact. As time passes, personal relationships that began with frequent contact begin to wane. Whereas much research on personal relationships focuses on ties that become stronger over time (e.g., Levinthal and Fichman 1988; Karolyi 2013), many organizationally-mediated relationships unfold predictably in the opposite direction. Rather than becoming stronger, front-heavy relationships between intermediaries and clients decay over time. The extent to which clients and intermediaries enjoy advantages via front-heavy relationships may hinge on the strength of that relationship.

This observation complicates a common perception that personal relationships between intermediaries and clients tend to facilitate improved organizational outcomes. For example, scholars of public service organizations have argued that more relational, humane approaches to client-facing interactions can foster more effective service delivery (Denhardt and Denhardt 2000; Jos and Tompkins 2009). The present study suggests that such benefits may be limited to a "honeymoon period" immediately following relationship formation. As front-heavy relationships weaken with decreased interaction, clients may feel less inclined to display the heightened levels of compliance and collaboration that they demonstrate at the outset.

This study suggests that "front-heavy" relationships follow a unique temporal trajectory that can pattern organizational outcomes. While such relationships may generate mutual benefits in the short-term, the benefits that intermediaries and their organizations accrue may be limited to an initial grace period when relationships are young and strong. This observation-along with data limitations in this study_ present new avenues for exploring temporal effects. MicroBank policy and qualitative observations suggest that original officers and clients rarely interact after the initial vetting, but the data do not capture the frequency of post-vetting interactions. Future 
research should examine intermediaries' and clients' behaviors when follow-up interactions are measured systematically. Such research would offer insights into how intermediaries can effectively revive or maintain the strong ties established at the outset of front-heavy relationships, thereby extending the relational benefits beyond a honeymoon period. In conclusion, this paper examines how personal relationships between intermediaries and clients shape financial outcomes. By examining how relationships affect both intermediaries' commitment and clients' compliance, this study integrates theoretical concepts from economic sociology and social psychology to offer a more comprehensive and temporally-informed understanding of personal relationships in financial intermediation. In doing so, it demonstrates how personal ties mediated by formal organizations generate shifting costs and benefits as relationships evolve. 


\section{DATA APPENDIX}

Qualitative Data Collection.-Between December 2009 and January 2013, I conducted nearly 200 hours of ethnographic observations with MicroBank loan officers and administrators. During this time, I shadowed 27 loan officers in two branches as they recruited, evaluated, and monitored clients. Since new officers shadow experienced officers for their first three months, the presence of an additional novice was not unusual. Much like a new loan officer, I asked questions about determining creditworthiness, working with problematic clients, and encouraging repayment. I observed 21 client evaluations and 10 follow-up visits. Additionally, I accompanied collections officers on five client visits. These visits helped me understand the consequences clients face if they repeatedly miss payments.

Beyond these activities, I attended staff meetings, helped officers complete client reports, and watched as branch managers dealt with officer departures. I also attended two weeklong training workshops for new officers. These experiences gave me a strong grounding in the bank's official and unofficial policies. Moreover, observing two branch offices allowed me to see the consistency with which policies applied across different settings.

To bolster the field observations, I conducted seven interviews with officers and two interviews with senior bank administrators. These interviews allowed me to explore issues that were not directly observable or were too sensitive to discuss in public. The interviews were semistructured and lasted approximately one hour. All interviews, with the exception of one administrator interview, were recorded and transcribed. 


\section{REFERENCES}

Abolafia, Mitchel. 1996. Making Markets: Opportunism and Restraint on Wall Street. Cambridge, Mass.: Harvard University Press.

Ai, Chunrong, and Edward C. Norton. 2003. "Interaction Terms in Logit and Probit Models." Economics Letters 80 (1): 123-29.

Allison, Paul. 1982. "Discrete-Time Methods for the Analysis of Event Histories." Sociological Methodology 13: 61-98. . 1984. Event History Analysis: Regression for Longitudinal Event Data. Vol. no. 07-046. Sage University Papers. Quantitative Applications in the Social Sciences. Beverly Hills, Calif.: Sage Publications.

—. 2014. Event History and Survival Analysis. Los Angeles: SAGE.

Ang, James, Jess Chua, and Clinton Bowing. 1979. "The Profiles of Late-Paying Consumer Loan Borrowers: An Exploratory Study.” Journal of Money, Credit and Banking 11 (2): 22226.

Armendariz de Aghion, Beatriz, and Jonathan Morduch. 2005. The Economics of Microfinance. Cambridge, Mass.: MIT Press.

Astebro, Thomas, Scott Jeffrey, and Gordon Adomdza. 2007. "Inventor Perseverance after Being Told to Quit: The Role of Cognitive Biases." Journal of Behavioral Decision Making 20 (3): 253-72. doi:10.1002/bdm.554.

Baker, Wayne E. 1984. "The Social Structure of a National Securities Market.” American Journal of Sociology 89 (4): 775-811.

Baklouti, Ibtissem. 2013. "Determinants of Microcredit Repayment: The Case of Tunisian Microfinance Bank." African Development Review 25 (3): 370-82.

Battilana, Julie, and Silvia Dorado. 2010. "Building Sustainable Hybrid Organizations: The Case of Commercial Microfinance Organizations.” Academy of Management Journal 53 (6): 1419-40.

Berger, Allen, Leora F. Klapper, and Gregory F. Udell. 2001. "The Ability of Banks to Lend to Informationally Opaque Small Businesses.” Journal of Banking and Finance 25: 212767.

Berger, Allen, and Gregory F. Udell. 1995. "Relationship Lending and Lines of Credit in Small Firm Finance." The Journal of Business 68 (3): 351-81.

Blossfeld, Hans-Peter, Katrin Golsch, and Götz Rohwer. 2007. Event History Analysis with Stata. Mahwah, N.J.: Lawrence Erlbaum Associates.

Box-Steffensmeier, Janet M., and Christopher Zorn. 2002. "Duration Models for Repeated Events." The Journal of Politics 64 (4): 1069-94.

Bragg, Steven M. 2005. Billing and Collections: Best Practices. Hoboken, N.J.: John Wiley \& Sons.

Brockner, Joel. 1992. "The Escalation of Commitment to a Failing Course of Action: Toward Theoretical Progress." The Academy of Management Review 17 (1): 39-61.

Broschak, Joseph P. 2004. 'Managers' Mobility and Market Interface: The Effect of Managers' Career Mobility on the Dissolution of Market Ties." Administrative Science Quarterly 49 (4): 608-40.

Bygrave, William D., and Jeffry A. Timmons. 1992. Venture Capital at the Crossroads. Boston, Mass.: Harvard Business School Press. 
Caldwell, David F., and Charles A. O'Reilly. 1982. "Responses to Failure: The Effects of Choice and Responsibility on Impression Management." Academy of Management Journal 25 (1): 121-36.

Campbell, Katharine. 2003. Smarter Ventures: A Survivor's Guide to Venture Capital. Harlow: Financial Times Prentice Hall.

Canales, Rodrigo. 2014. "Weaving Straw into Gold: Managing Organizational Tensions Between Standardization and Flexibility in Microfinance." Organization Science 25 (1): 1-28. doi:10.1287/orsc.2013.0831.

Canales, Rodrigo, and Jason Greenberg. 2015. “A Matter of (Relational) Style: Loan Officer Consistency and Exchange Continuity in Microfinance." Management Science, September, 1-23.

Chan, Cheris Shun-ching. 2009. "Invigorating the Content in Social Embeddedness: An Ethnography of Life Insurance Transactions in China." American Journal of Sociology 115 (3): 712-54.

Coleman, James Samuel. 1990. Foundations of Social Theory. Cambridge, MA: Belknap Press of Harvard University Press.

Conlon, Edward J., and Judi McLean Parks. 1987. "Information Requests in the Context of Escalation." Journal of Applied Psychology 72 (3): 344-50.

Delios, Andrew, Andrew C. Inkpen, and Jerry Ross. 2004. "Escalation in International Strategic Alliances." MIR: Management International Review 44 (4): 457-79.

Denhardt, Robert B, and Janet Vinzant Denhardt. 2000. "The New Public Service: Serving Rather than Steering." Public Administration Review 60 (6): 549-59. doi:10.1111/00333352.00117.

D’Espallier, Bert, Isabelle Guerin, and Roy Mersland. 2013. "Focus on Women in Microfinance Institutions." Journal of Development Studies 49 (5): 589-608.

Doering, Laura, and Sarah Thébaud. 2017. "The Effects of Gendered Occupational Roles on Men's and Women's Workplace Authority: Evidence from Microfinance." American Sociological Review 82 (3): 542-67.

Espeland, Wendy Nelson, and Mitchell L Stevens. 1998. "Commensuration as a Social Process." Annu. Rev. Sociol. Annual Review of Sociology 24 (1): 313-43.

Ezell, Michael E., Kenneth C. Land, and Lawrence E. Cohen. 2003. "Modeling Multiple Failure Time Data: A Survey of Variance-Corrected Proportional Hazards Models with Empirical Applications to Arrest Data." Sociological Methodology 33: 111-67.

Gans, Herbert J. 1995. The War against the Poor: The Underclass and Antipoverty Policy. New York, NY: BasicBooks.

Geertz, Clifford. 1963. Peddlers and Princes: Social Change and Economic Modernization in Two Indonesian Towns. Chicago: University of Chicago Press.

Granovetter, Mark. 1973. "The Strength of Weak Ties." American Journal of Sociology 78 (6): 1360-80.

- 1985. "Economic Action and Social Structure: The Problem of Embeddedness." The American Journal of Sociology 91 (3): 481-510.

- 1995. "The Economic Sociology of Firms and Entrepreneurs." In The Economic Sociology of Immigration : Essays on Networks, Ethnicity, and Entrepreneurship, 12865. New York: Russell Sage Foundation.

Gulati, Ranjay, and Martin Gargiulo. 1999. "Where Do Interorganizational Networks Come From?” American Journal of Sociology. 
Guler, Isin. 2007. "Throwing Good Money after Bad? Political and Institutional Influences on Sequential Decision Making in the Venture Capital Industry." Administrative Science Quarterly 52 (2): 248-85.

Guseva, Alya, and Akos Rona-Tas. 2001. "Uncertainty, Risk, and Trust: Russian and American Credit Card Markets Compared." American Sociological Review 66 (5): 623-46.

Haile, Firafis. 2015. "Determinants of Loan Repayment Performance: The Case Study of Harari Microfinance Institutions." International Journal of Research in Commerce, Economics and Management 5 (3): 65-70.

Hochschild, Arlie Russell. 1983. The Managed Heart: Commercialization of Human Feeling. Berkeley: University of California Press.

Homans, George Caspar. 1950. The Human Group. New York: Harcourt.

Ingram, Paul, and Peter W. Roberts. 2000. "Friendships among Competitors in the Sydney Hotel Industry." American Journal of Sociology 106 (2): 387-423.

Jos, Philip H., and Mark E. Tompkins. 2009. "Keeping It Public: Defending Public Service Values in a Customer Service Age.” Public Administration Review 69 (6): 1077-86. doi:10.1111/j.1540-6210.2009.02065.x.

Karlan, Dean, Melanie Morten, and Jonathan Zinman. 2015. "A Personal Touch: Text Messaging for Loan Repayment." Behavioral Science and Policy 1 (2): 25-32.

Karolyi, Stephen. 2013. "Personal Lending Relationships." Yale University Working Paper.

Katz, Michael B. 1989. The Undeserving Poor: From the War on Poverty to the War on Welfare. 1st ed. New York: Pantheon Books.

Kelly, Theresa, and Katherine L. Milkman. 2013. "Escalation of Commitment." In Encyclopedia of Management Theory, edited by E.H. Kessler. Thousand Oaks, Calif.: Sage Publications, Inc.

King, Gary, and Langche Zeng. 2001. "Logistic Regression in Rare Events Data." Political Analysis 9 (2): 137-63.

Krippner, Greta R., and Anthony S. Alvarez. 2007. "Embeddedness and the Intellectual Projects of Economic Sociology.” Annual Review of Sociology 33 (January): 219-40.

Kwon, Seok-Woo, Colleen Heflin, and Martin Ruef. 2013. "Community Social Capital and Entrepreneurship." American Sociological Review 78 (6): 980-1008.

Levinthal, Daniel A., and Mark Fichman. 1988. "Dynamics of Interorganizational Attachments: Auditor-Client Relationships.” Administrative Science Quarterly 33 (3): 345-69.

Mizruchi, Mark S., and Linda Brewster Stearns. 2001. "Getting Deals Done: The Use of Social Networks in Bank Decision-Making." American Sociological Review 66 (5): 647-71.

Neter, John, William Wasserman, and Michael H. Kutner. 1989. Applied Linear Regression Models. Homewood, Ill.: Irwin.

Owens, Lindsay A. 2014. "Intrinsically Advantageous? Reexamining the Production of Class Advantage in the Case of Home Mortgage Modification." Social Forces, September, 125.

Petersen, Mitchell A., and Raghuram G. Rajan. 1994. "The Benefits of Lending Relationships: Evidence from Small Business Data." The Journal of Finance 49 (1): 3-37.

Portes, Alejandro, and Julia Sensenbrenner. 1993. "Embeddedness and Immigration: Notes on the Social Determinants of Economic Action." The American Journal of Sociology 98 (6): $1320-50$.

Ridgeway, Cecilia L. 2009. "Framed before We Know It: How Gender Shapes Social Relations." Gender and Society, no. 2: 145. 
Rivera, Mark T., Sara B. Soderstrom, and Brian Uzzi. 2010. "Dynamics of Dyads in Social Networks: Assortative, Relational, and Proximity Mechanisms." Annual Review of Sociology 36 (1): 91-115.

Rubin, Jeffrey Z., and Joel Brockner. 1975. "Factors Affecting Entrapment in Waiting Situations: The Rosencrantz and Guildenstern Effect." Journal of Personality \& Social Psychology 31 (6): 1054-63.

Sadoulet, Loïc. 2005. "Learning from Visa? Incorporating Insurance Provisions in Microfinance Contracts." In Insurance against Poverty, edited by Stefan Dercon. UNU-WIDER Studies in Development Economics. Oxford; New York: Oxford University Press.

Schoorman, F. David. 1988. "Escalation Bias in Performance Appraisals: An Unintended Consequence of Supervisor Participation in Hiring Decisions." Journal of Applied Psychology 73 (1): 58-62.

Seabright, Mark A., Daniel A. Levinthal, and Mark Fichman. 1992. "Role of Individual Attachments in the Dissolution of Interorganizational Relationships.” The Academy of Management Journal 35 (1): 122-60.

Simmel, Georg. 1971. On Individuality and Social Forms : Selected Writings. Edited by Donald Nathan Levine. The Heritage of Sociology. Chicago: University of Chicago Press.

Staw, Barry M. 1976. "Knee-Deep in the Big Muddy: A Study of Escalating Commitment to a Chosen Course of Action." Organizational Behavior \& Human Performance 16 (1): $27-$ 44.

Staw, Barry M., Sigal G. Barsade, and Kenneth W. Koput. 1997. "Escalation at the Credit Window: A Longitudinal Study of Bank Executives' Recognition and Write-Off of Problem Loans." Journal of Applied Psychology 82 (1): 130-42.

Staw, Barry M., and Ha Hoang. 1995. "Sunk Costs in the NBA: Why Draft Order Affects Playing Time and Survival in Professional Basketball." Administrative Science Quarterly 40 (3): 474-94.

Thompson, James D. 1967. Organizations in Action: Social Science Bases of Administrative Theory. New York: McGraw-Hill.

Uzzi, Brian. 1997. "Social Structure and Competition in Interfirm Networks: The Paradox of Embeddedness." Administrative Science Quarterly 42 (1): 35-67. . 1999. "Embeddedness in the Making of Financial Capital: How Social Relations and Networks Benefit Firms Seeking Financing." American Sociological Review 64 (4): $481-$ 505.

Uzzi, Brian, and Ryon Lancaster. 2003. "Relational Embeddedness and Learning: The Case of Bank Loan Managers and Their Clients." Management Science 49 (4): 383-99.

Whyte, Glen. 1986. "Escalating Commitment to a Course of Action: A Reinterpretation." Academy of Management Review 11 (2): 311-21. 
FIGURE 1

PREDICTED PROBABILITY OF COLLECTIONS BY RELATIONSHIP DURATION

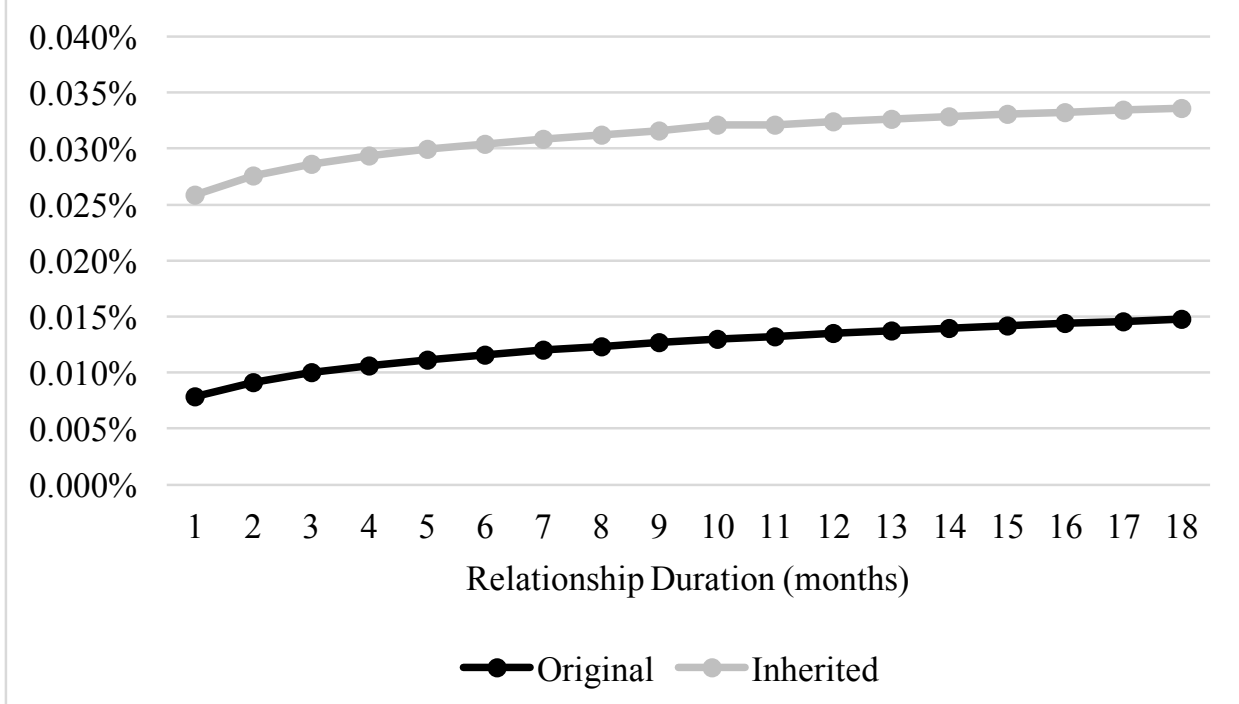

Note.-Original and inherited clients' predicted probabilities of being sent to collections are significantly different across all months. 
FIGURE 2

PREDICTED PROBABILITY OF MISSED PAYMENTS BY RELATIONSHIP DURATION

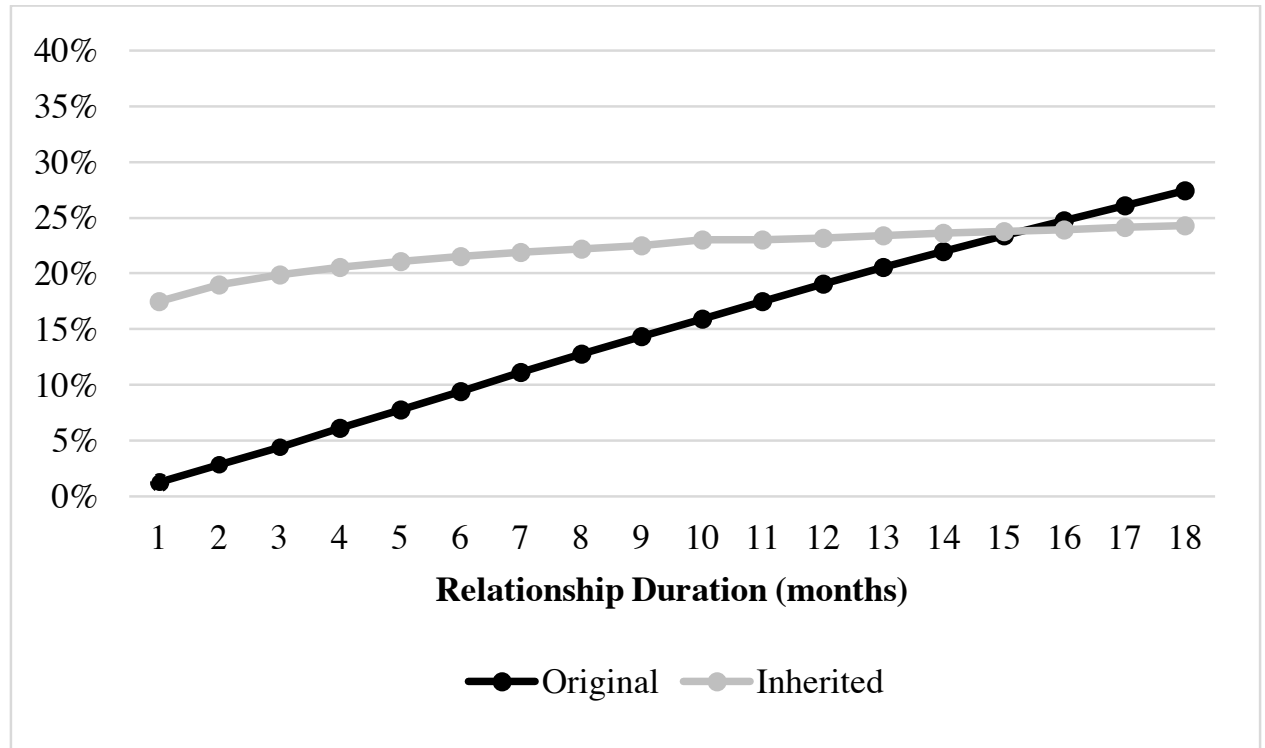

Note.-Original and inherited clients' probabilities of missed payments are significantly different in months $1-13$ and 18. 
TABLE 1

SUMMARY STATISTICS

\begin{tabular}{|c|c|c|c|c|c|c|c|c|c|c|c|c|c|c|c|c|c|c|c|}
\hline Variable & $\mathrm{N}$ & Means & SD & 1 & 2 & 3 & 4 & 5 & 6 & 7 & 8 & 9 & 10 & 11 & 12 & 13 & 14 & 15 & 16 \\
\hline 1. Original officer & 255,474 & 0.82 & 0.38 & 1.00 & & & & & & & & & & & & & & & \\
\hline 2. Relationship duration (ln) & 255,474 & 1.69 & 0.88 & 0.17 & 1.00 & & & & & & & & & & & & & & \\
\hline 3. Officer tenure & 255,474 & 30.73 & 20.27 & 0.23 & 0.37 & 1.00 & & & & & & & & & & & & & \\
\hline 4. Female officer & 255,474 & 0.58 & 0.49 & 0.08 & 0.08 & 0.19 & 1.00 & & & & & & & & & & & & \\
\hline 5. Commission (ln) & 255,474 & 5.47 & 1.63 & 0.16 & 0.14 & 0.20 & 0.03 & 1.00 & & & & & & & & & & & \\
\hline 6. Loan month & 255,474 & 9.32 & 7.13 & -0.28 & 0.72 & 0.28 & 0.04 & 0.04 & 1.00 & & & & & & & & & & \\
\hline 7. Loan amount (ln) & 255,474 & 7.74 & 1.24 & 0.12 & 0.25 & 0.22 & 0.10 & 0.13 & 0.29 & 1.00 & & & & & & & & & \\
\hline 8. Automobile loan & 255,474 & 0.25 & 0.44 & 0.18 & 0.25 & 0.19 & 0.11 & 0.15 & 0.24 & 0.83 & 1.00 & & & & & & & & \\
\hline 9. Remaining balance (\%) & 255,474 & 73.79 & 26.71 & 0.35 & -0.45 & -0.07 & 0.01 & 0.04 & -0.59 & 0.28 & 0.25 & 1.00 & & & & & & & \\
\hline 10. Cumul. missed payments (\%) & 255,474 & 8.15 & 17.67 & -0.13 & 0.21 & 0.07 & 0.06 & -0.03 & 0.25 & -0.10 & -0.05 & -0.25 & 1.00 & & & & & & \\
\hline 11. Household income (ln) & 255,474 & 7.20 & 0.93 & 0.07 & 0.11 & 0.16 & 0.02 & 0.07 & 0.12 & 0.50 & 0.36 & 0.11 & -0.04 & 1.00 & & & & & \\
\hline 13. Previous MicroBank loan & 255,474 & 0.34 & 0.48 & -0.03 & -0.01 & 0.09 & -0.02 & -0.01 & 0.00 & -0.06 & -0.20 & -0.02 & -0.02 & -0.02 & 0.16 & 1.00 & & & \\
\hline 14. Female client & 255,474 & 0.43 & 0.49 & -0.02 & -0.04 & -0.03 & 0.05 & -0.01 & -0.05 & -0.16 & -0.12 & -0.03 & 0.03 & -0.12 & -0.02 & 0.03 & 1.00 & & \\
\hline 15. Family size & 255,474 & 2.90 & 1.56 & -0.01 & -0.01 & -0.02 & -0.04 & 0.01 & -0.01 & -0.04 & -0.05 & 0.00 & -0.01 & -0.03 & 0.05 & -0.01 & -0.03 & 1.00 & \\
\hline 16. Married client & 255,474 & 0.61 & 0.49 & 0.03 & 0.06 & 0.04 & 0.00 & 0.02 & 0.06 & 0.17 & 0.14 & 0.04 & -0.07 & 0.10 & 0.10 & -0.04 & -0.17 & 0.47 & 1.00 \\
\hline
\end{tabular}


TABLE 2

DISCRETE-TIME LOGISTIC REGRESSION

PREDICTING CLIENT TRANSFER TO COLLECTIONS DEPARTMENT (H1)

\begin{tabular}{|c|c|c|c|c|c|}
\hline & Model 1 & Model 2 & $\begin{array}{l}\text { Model } 3 \\
\text { (Rare Event) }\end{array}$ & Model 4 & $\begin{array}{l}\text { Model 5 } \\
\text { (Rare Event) }\end{array}$ \\
\hline \multirow[t]{2}{*}{ Original Officer............................. } & & $0.395^{* * *}$ & $0.395 * * *$ & $0.304 *$ & $0.311 *$ \\
\hline & & $(0.091)$ & $(0.091)$ & $(0.163)$ & $(0.167)$ \\
\hline \multirow[t]{2}{*}{ Relationship Duration $(\ln ) \ldots \ldots \ldots \ldots \ldots \ldots \ldots$} & 0.839 & 1.166 & 1.157 & 1.094 & 1.090 \\
\hline & $(0.083)$ & $(0.169)$ & $(0.168)$ & $(0.171)$ & $(0.170)$ \\
\hline \multirow[t]{2}{*}{ Original Officer X Relationship Duration (ln) } & & & & 1.136 & 1.122 \\
\hline & & & & $(0.245)$ & $(0.242)$ \\
\hline \multirow[t]{2}{*}{ Officer Tenure $\ldots \ldots \ldots \ldots \ldots \ldots \ldots \ldots \ldots \ldots \ldots \ldots \ldots \ldots \ldots \ldots$} & 0.995 & 0.998 & 0.998 & 0.998 & 0.998 \\
\hline & $(0.004)$ & $(0.004)$ & $(0.004)$ & $(0.004)$ & $(0.004)$ \\
\hline \multirow[t]{2}{*}{ Female Officer.............................. } & 1.044 & 1.011 & 1.008 & 1.014 & 1.012 \\
\hline & $(0.173)$ & $(0.164)$ & $(0.163)$ & $(0.164)$ & $(0.164)$ \\
\hline \multirow[t]{2}{*}{ 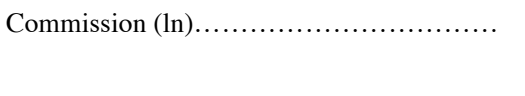 } & 1.062 & 1.078 & 1.076 & 1.077 & 1.076 \\
\hline & $(0.049)$ & $(0.051)$ & $(0.051)$ & $(0.051)$ & $(0.050)$ \\
\hline \multirow[t]{2}{*}{ Loan Month................................... } & $1.202 * * *$ & $1.169^{* * *}$ & $1.169 * * *$ & $1.165^{* * *}$ & $1.165 * * *$ \\
\hline & $(0.020)$ & $(0.021)$ & $(0.021)$ & $(0.023)$ & $(0.023)$ \\
\hline \multirow[t]{2}{*}{ 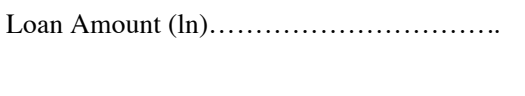 } & $0.719^{*}$ & $0.730 *$ & $0.733 *$ & $0.732 *$ & $0.735^{*}$ \\
\hline & $(0.098)$ & $(0.099)$ & $(0.099)$ & $(0.100)$ & $(0.100)$ \\
\hline \multirow[t]{2}{*}{ Automobile Loan............................ } & $4.914 * * *$ & $5.605 * * *$ & $5.546 * * *$ & $5.604 * * *$ & $5.544 * * *$ \\
\hline & $(1.918)$ & $(2.140)$ & (2.118) & $(2.135)$ & $(2.112)$ \\
\hline \multirow[t]{2}{*}{ Remaining Balance $(\%) \ldots \ldots \ldots \ldots \ldots \ldots \ldots$} & $1.085^{* * *}$ & $1.086^{* * *}$ & $1.086 * * *$ & $1.086^{* * *}$ & $1.085 * * *$ \\
\hline & $(0.011)$ & $(0.011)$ & $(0.011)$ & $(0.011)$ & $(0.011)$ \\
\hline \multirow[t]{2}{*}{ Cumulative Missed Payments $(\%) \ldots \ldots \ldots \ldots \ldots$} & $1.059 * * *$ & $1.058 * * *$ & $1.058 * * *$ & $1.058 * * *$ & $1.058 * * *$ \\
\hline & $(0.002)$ & $(0.002)$ & $(0.002)$ & $(0.002)$ & $(0.002)$ \\
\hline \multirow[t]{2}{*}{ Household Income $(\ln ) \ldots \ldots \ldots \ldots \ldots \ldots \ldots \ldots$} & 1.176 & 1.151 & 1.151 & 1.153 & 1.153 \\
\hline & $(0.099)$ & $(0.095)$ & $(0.095)$ & $(0.094)$ & $(0.094)$ \\
\hline \multirow[t]{2}{*}{ 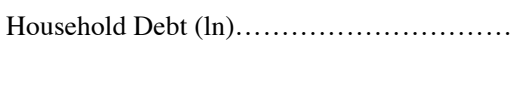 } & $1.039 *$ & $1.038^{*}$ & $1.038^{*}$ & $1.037 *$ & $1.037 *$ \\
\hline & $(0.019)$ & $(0.018)$ & $(0.018)$ & $(0.018)$ & $(0.018)$ \\
\hline \multirow[t]{2}{*}{ Previous MicroBank Loan..................... } & 1.184 & 1.204 & 1.206 & 1.206 & 1.207 \\
\hline & $(0.189)$ & $(0.191)$ & $(0.191)$ & $(0.191)$ & $(0.191)$ \\
\hline \multirow[t]{2}{*}{ Female Client.............................. } & 1.048 & 1.033 & 1.034 & 1.036 & 1.037 \\
\hline & $(0.149)$ & $(0.144)$ & $(0.144)$ & $(0.145)$ & $(0.145)$ \\
\hline \multirow[t]{2}{*}{ Family Size..$\ldots \ldots \ldots \ldots \ldots \ldots \ldots \ldots \ldots \ldots \ldots \ldots \ldots \ldots \ldots \ldots \ldots \ldots \ldots$} & $1.095^{* *}$ & $1.095^{* *}$ & $1.102 * * *$ & $1.094 * *$ & $1.100 * * *$ \\
\hline & $(0.032)$ & $(0.031)$ & $(0.031)$ & $(0.032)$ & $(0.032)$ \\
\hline \multirow[t]{2}{*}{ Married Client................................ } & 1.029 & 1.025 & 1.015 & 1.026 & 1.016 \\
\hline & $(0.163)$ & $(0.158)$ & $(0.157)$ & $(0.159)$ & $(0.157)$ \\
\hline 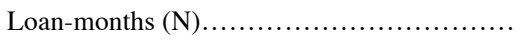 & 255,474 & 255,474 & 255,474 & 255,474 & 255,474 \\
\hline Loans $(\mathrm{N}) \ldots \ldots \ldots \ldots \ldots \ldots \ldots$ & 19,721 & 19,721 & 19,721 & 19,721 & 19,721 \\
\hline Chi-Squared............................... & - & $16.14 * * *$ & $16.11 * * *$ & 0.35 & 0.29 \\
\hline
\end{tabular}


TABLE 3

DISCRETE-TIME LOGISTIC REGRESSIONS PREDICTING MISSED PAYMENTS (H2 \& H3)

\begin{tabular}{|c|c|c|c|}
\hline & Model 1 & Model 2 & Model 3 \\
\hline \multirow[t]{2}{*}{ Original Officer............................ } & & $0.395 * * *$ & $0.060 * * *$ \\
\hline & & $(0.014)$ & $(0.004)$ \\
\hline \multirow[t]{2}{*}{ Relationship Duration $(\ln ) \ldots \ldots \ldots \ldots \ldots \ldots \ldots$} & $1.455 * * *$ & $2.062 * * *$ & $1.154 * * *$ \\
\hline & $(0.027)$ & $(0.044)$ & $(0.035)$ \\
\hline \multirow[t]{2}{*}{ Original Officer X Relationship Duration (ln) } & & & $2.797 * * *$ \\
\hline & & & $(0.096)$ \\
\hline \multirow[t]{2}{*}{ Officer Tenure..$\ldots \ldots \ldots \ldots \ldots \ldots \ldots \ldots \ldots \ldots \ldots \ldots \ldots$} & $0.998 * *$ & 1.001 & 1.001 \\
\hline & $(0.001)$ & $(0.001)$ & $(0.001)$ \\
\hline \multirow[t]{2}{*}{ Female Officer............................... } & $1.282 * * *$ & $1.290 * * *$ & $1.275^{* * *}$ \\
\hline & $(0.037)$ & $(0.038)$ & $(0.037)$ \\
\hline \multirow[t]{2}{*}{ Commission $(\ln ) \ldots \ldots \ldots \ldots \ldots \ldots \ldots \ldots \ldots \ldots$} & $0.965 * * *$ & $0.971^{* * *}$ & $0.982 * *$ \\
\hline & $(0.006)$ & $(0.006)$ & $(0.006)$ \\
\hline \multirow[t]{2}{*}{ Loan Month..................................... } & $1.071 * * *$ & $1.025^{* * *}$ & 0.999 \\
\hline & $(0.003)$ & $(0.003)$ & $(0.003)$ \\
\hline \multirow[t]{2}{*}{ Loan Amount $(\ln ) \ldots \ldots \ldots \ldots \ldots \ldots \ldots \ldots \ldots \ldots \ldots$} & $0.542 * * *$ & $0.544^{* * *}$ & $0.553 * * *$ \\
\hline & $(0.014)$ & $(0.014)$ & $(0.015)$ \\
\hline \multirow[t]{2}{*}{ Automobile Loan............................. } & $1.342 * * *$ & $1.612 * * *$ & $1.524 * * *$ \\
\hline & $(0.100)$ & $(0.121)$ & $(0.113)$ \\
\hline \multirow[t]{2}{*}{ Household Income $(\ln ) \ldots \ldots \ldots \ldots \ldots \ldots \ldots$} & $1.095 * * *$ & $1.099 * * *$ & $1.094 * * *$ \\
\hline & $(0.021)$ & $(0.021)$ & $(0.021)$ \\
\hline \multirow[t]{2}{*}{ Household Debt $(\ln ) \ldots \ldots \ldots \ldots \ldots \ldots \ldots \ldots \ldots$} & $0.978 * * *$ & $0.975^{* * *}$ & $0.973 * * *$ \\
\hline & $(0.004)$ & $(0.004)$ & $(0.004)$ \\
\hline \multirow[t]{2}{*}{ Previous MicroBank Loan...................... } & $0.897 * *$ & $0.896 * *$ & $0.901 * *$ \\
\hline & $(0.031)$ & $(0.031)$ & $(0.031)$ \\
\hline \multirow[t]{2}{*}{ Female Client................................ } & 0.988 & 0.988 & 0.989 \\
\hline & $(0.031)$ & $(0.031)$ & $(0.031)$ \\
\hline \multirow[t]{2}{*}{ Family Size $\ldots \ldots \ldots \ldots \ldots \ldots \ldots \ldots \ldots \ldots \ldots \ldots \ldots \ldots \ldots \ldots$} & $1.048 * * *$ & $1.049 * * *$ & $1.047 * * *$ \\
\hline & $(0.010)$ & $(0.011)$ & $(0.011)$ \\
\hline \multirow[t]{2}{*}{ Married Client..$\ldots \ldots \ldots \ldots \ldots \ldots \ldots \ldots \ldots \ldots \ldots \ldots \ldots$} & $0.687 * * *$ & $0.686^{* * *}$ & $0.684 * * *$ \\
\hline & $(0.024)$ & $(0.024)$ & $(0.024)$ \\
\hline 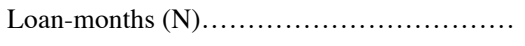 & 255,474 & 255,474 & 255,474 \\
\hline 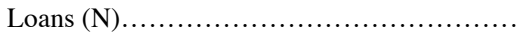 & 19,721 & 19,721 & 19,721 \\
\hline Chi-Squared $\ldots \ldots \ldots \ldots \ldots \ldots \ldots \ldots \ldots \ldots \ldots \ldots$ & - & $654.60 * * *$ & $905.67 * * *$ \\
\hline
\end{tabular}




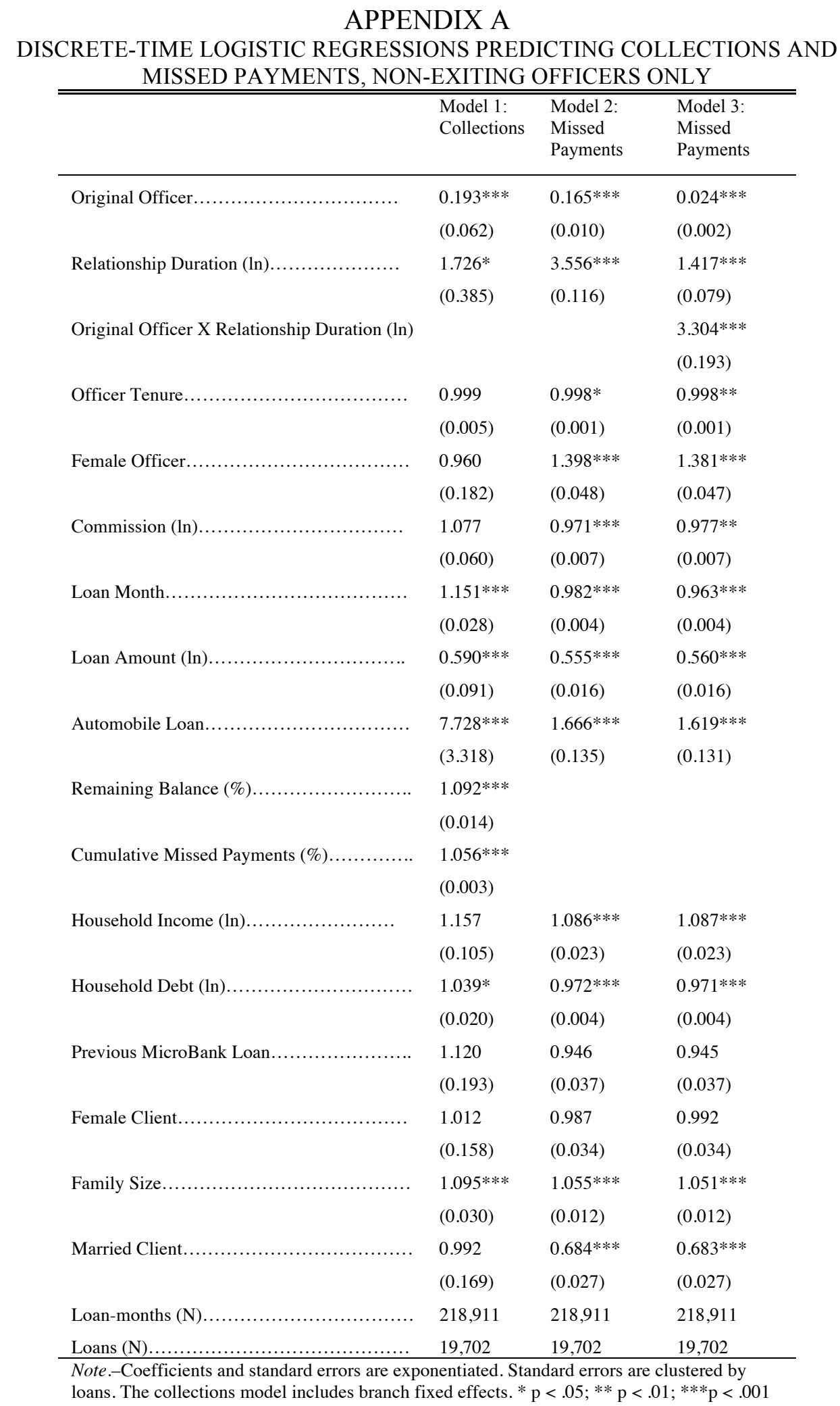




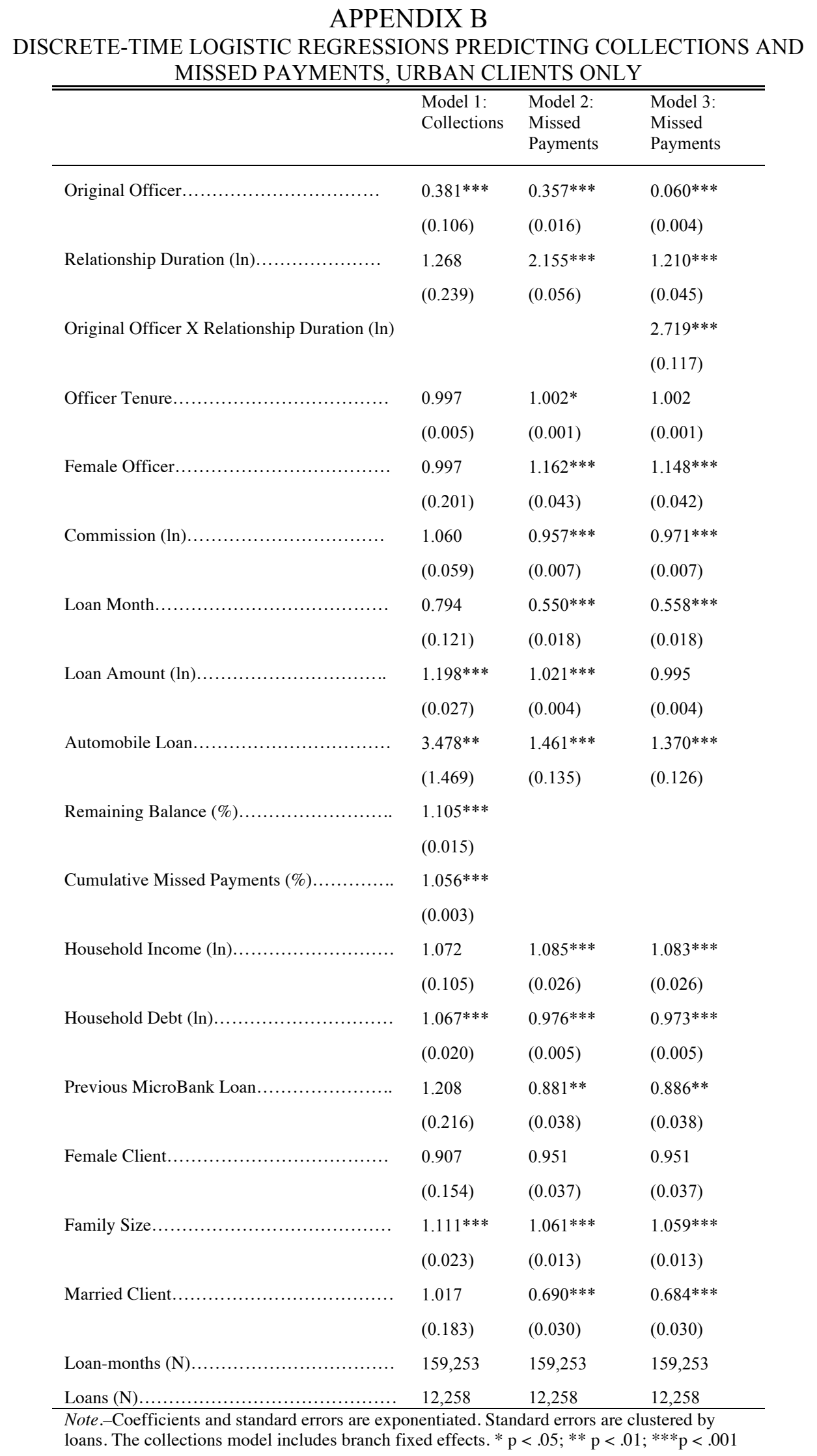




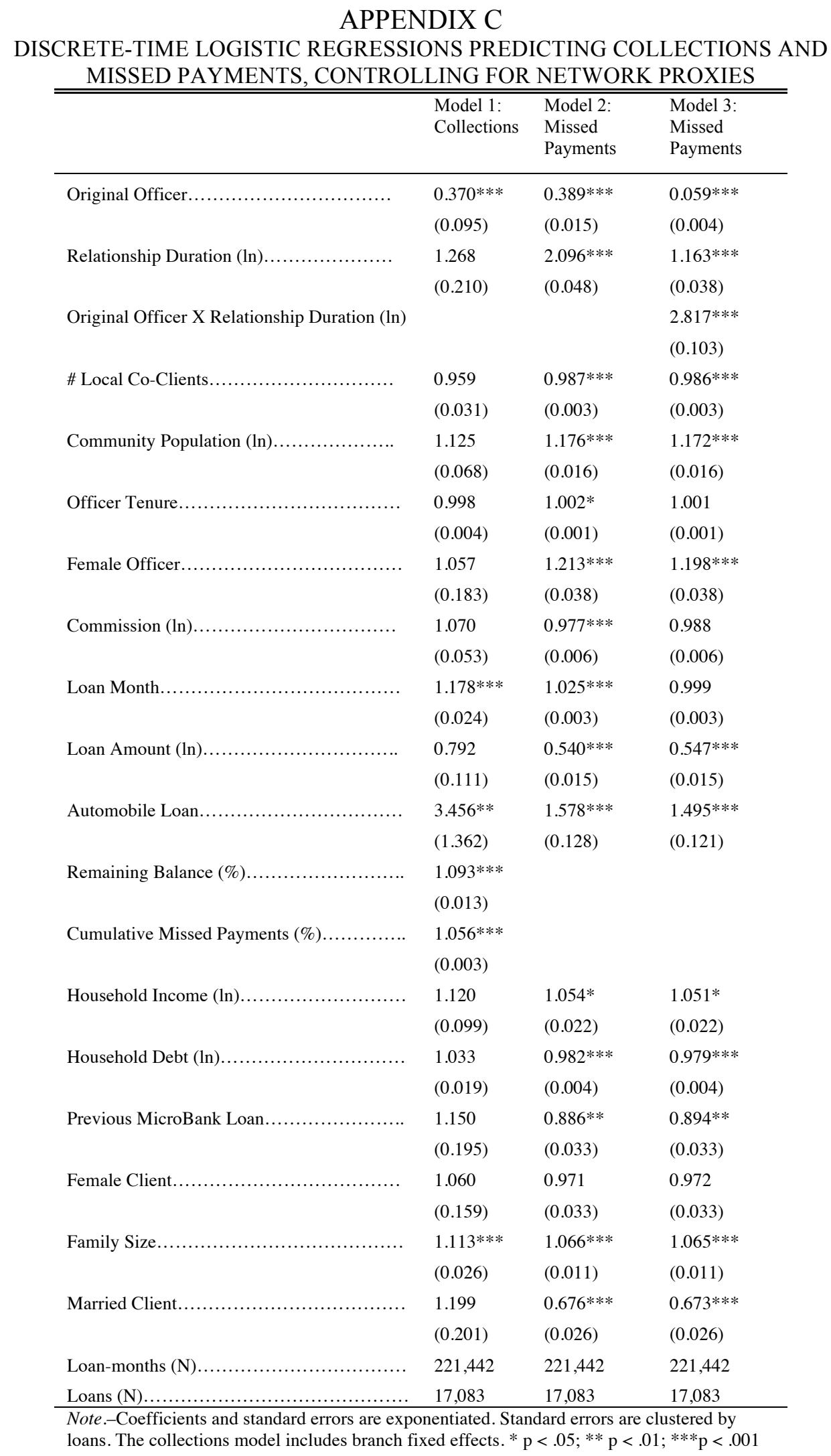




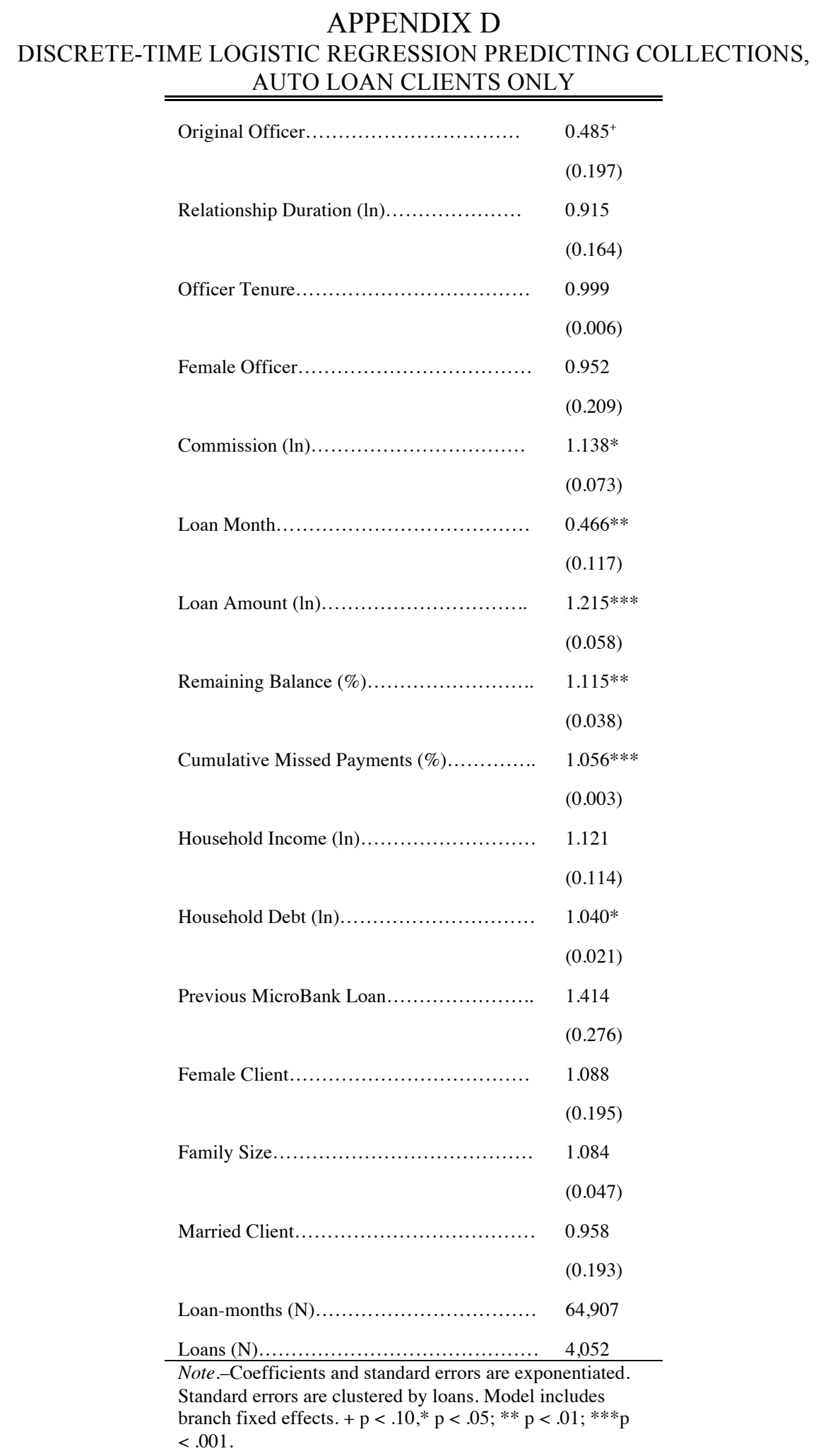

